\title{
The Impact of Presymptomatic Molecular Testing in Hereditary Cancers
}

\section{Fiona Macdonald}

DNA Laboratory, Regional Genetics Laboratory, Birmingham Women's Hospital, Birmingham, UK

\author{
Key Words \\ Hereditary cancer - Presymptomatic \\ mutation
}

\section{Introduction}

Genetic factors are likely to be the primary determinants in around $5-10 \%$ of cancer patients. Over the last decade the identification of some of these cancer susceptibility genes has revolutionised our understanding of cancer in general. In addition, it has allowed us to improve our management of patients in those families with a genetic predisposition by offering presymptomatic testing and hence early intervention and treatment for the disease. This review will examine the major hereditary cancer syndromes and look at the tests currently available for their diagnosis.

\begin{tabular}{ll}
\hline KARGER & ( 2001 S. Karger AG, Basel \\
Fax +41 61 306 1234 $34-7571 / 00 / 0094-0221 \$ 17.50 / 0$ \\
$\begin{array}{l}\text { E-Mail karger@karger.ch } \\
\text { www.karger.com }\end{array}$ & $\begin{array}{l}\text { Accessible online at: } \\
\text { www.karger.com/journals/mpp }\end{array}$
\end{tabular}

\section{Molecular Changes Associated with the Development of Cancers}

The development of any tumour is a multistage process involving mutations in a number of genes. Some mutations are found in genes which promote cell proliferation, increasing the target cell population and thus making it more likely that subsequent changes will occur. Other mutations affect the stability of the genome e.g. by affecting genes associated with DNA repair processes and thereby increase the overall mutation rates. In the $1950 \mathrm{~s}$ it was estimated that 6-7 successive changes would be required to convert a normal cell into a malignant one. This explained in part why the majority of cancers are diseases of older age groups, as it will take some time for each of these steps to occur. In inherited cancers, the first mutation is inherited in the germ line hence the cancers are likely to occur at an earlier age. Several groups of genes are associated with cancers, most notably the oncogenes and tumour suppressor genes [1].

\footnotetext{
Fiona Macdonald, DNA Laboratory

Regional Genetics Laboratory, Birmingham Women's Hospital

Edgbaston, Birmingham B15 2TG (UK)

Tel. +44 1216272710 , Fax +44 121627271

E-Mail fiona.macdonald@bham-womens.thenhs.com
} 


\section{Oncogenes}

These genes belong to groups of genes which in their normal state, termed protooncogenes, control cell proliferation. The protein products of the proto-oncogenes function at all levels of the cell and belong to one of five groups: growth factors, factor receptors, components of the signal transfuction pathways, DNA binding proteins or proteins controlling the cell cycle. Mutation of the genes occurs either through point mutation, amplification, chromosome translocation leading to production of fusion genes or chromosome translocations resulting in loss of control of gene expression. Each of these mutations are gain of function mutations, resulting in inappropriate or excessive expression of the gene [1]. These changes act in a dominant manner with only one mutation in the gene being necessary. Many different oncogenes have been identified in a wide range of tumours. Initially it was believed that oncogenes would not be associated with inherited cancers as they were thought to be lethal. There is however one exception to this, the RET oncogene, which causes multiple endocrine neoplasia, which is discussed below.

\section{Tumour Suppressor Genes}

The existence of this group of genes had been known for many years. Experiments indicated that the normal phenotype could be restored by fusion of a malignant cell with a normal one [1]. This provided the first evidence for recessive, loss of function mutations in genes. Direct evidence for a tumour suppressor gene came from studies of the rare childhood tumour retinoblastoma. In 1971, Knudson [1] proposed that two 'hits' in the retinoblastoma gene would be required before the tumour could develop. In the sporadic form of the condition, two separate mutations would be necessary for tumour development and hence it was likely that the disease would occur at a later age and would be unilateral. In the familial form of retinoblastoma, one mutation would be present in all cells of the body as it is inherited in the germ line and hence earlier ages of onset and the frequent occurrence of bilateral tumours would be more likely. This is in fact what is seen in sporadic and familial retinoblastomas. Molecular studies during the 1980s confirmed this two-hit hypothesis using the so-called loss of heterozygosity test. DNA from both blood and tumour were compared, using polymorphic markers from a region close to the retinoblastoma gene on chromosome 13. Markers which were heterozygous in DNA from normal tissue where shown to be apparently homozygous in tumour DNA. In fact, the DNA from the tumour contained only one mutated copy of the gene and the second copy of the gene had been lost. Hence the polymorphic marker was present in the hemizygous state. This confirmed Knudson's two-hit hypothesis. The first hit in the gene was usually a point mutation and the second hit, occurring in the tumour, was usually a deletion of the second copy. This therefore also led to loss of one copy of the polymorphic marker resulting in loss of heterozygosity. This type of analysis with markers from throughout the genome led to the identification of further tumour suppressor genes, many of which were shown to be the cause of hereditary cancers. In each case, the earlier onset of inherited disease could be explained by the existence of one mutation in all cells of the body with a second hit in the wild-type copy of the gene occurring in the majority of cases. Although these mutations are recessive at the level of the cell, the cancers are dominantly inherited as the second hit is almost certain to occur and it is rare for a tumour not to develop. 
Table 1. Hereditary cancers and their associated genes

\begin{tabular}{|c|c|c|}
\hline Disease & Gene & Major associated cancers \\
\hline Familial adenomatous polyposis & APC & colorectal \\
\hline Hereditary non-polyposis colon cancer & $\begin{array}{l}\text { MSH2/MLH1 } \\
\text { PMS1/PMS2 } \\
\text { MSH6 }\end{array}$ & $\begin{array}{l}\text { colorectal, endometrial, small intestine, } \\
\text { hepatobiliary, pancreatic, ureter and renal pelvis }\end{array}$ \\
\hline Breast/ovarian cancer & BRCA1, BRCA2 & breast, ovarian, pancreatic, laryngeal \\
\hline Von Hippel-Lindau & VHL & $\begin{array}{l}\text { retinal angioma, renal cell cancer, } \\
\text { haemangioblastoma, phaeochromocytoma }\end{array}$ \\
\hline Gastric cancer & $\mathrm{CDH} 1$ & gastric cancer \\
\hline Multiple endocrine neoplasia 1 & MEN1 & $\begin{array}{l}\text { parathyroid, anterior pituitary, } \\
\text { endocrine pancreas }\end{array}$ \\
\hline Multiple endocrine neoplasia 2 & RET & medullary thyroid cancer, phaeochromocytoma \\
\hline Gorlin's syndrome & PTCH & basal cell carcinomas \\
\hline Peutz-Jeghers syndrome & LKB1 & $\begin{array}{l}\text { intestinal hamartomas, colorectal cancer, } \\
\text { breast cancer }\end{array}$ \\
\hline Cowden's disease & PTEN & $\begin{array}{l}\text { skin and mucous membrane hamartomas, } \\
\text { breast cancer }\end{array}$ \\
\hline Renal cell cancer & MET & renal cell cancer \\
\hline
\end{tabular}

\section{Inherited Cancer Syndromes}

Inherited cancer syndromes can be recognised by a number of features such as an earlier age at onset than is normal for the cancer, the presence of multiple tumours or bilateral disease, a familial clustering of cancers and segregation of the disease in a Mendelian manner. Some of the hereditary conditions and their associated genes are listed in table 1 .

Recognition of a genetic predisposition in a family means that they can be offered clinical screening. However, in the majority of these syndromes, the disease segregates in an autosomal dominant manner, which means that $50 \%$ of the offspring will develop the disease and $50 \%$ will not. Screening by clinical methods necessarily means that all individuals will have to have regular invasive procedures which can be unpleasant and stressful for the patient as well as costly for the provision of health services. The identification of

The Impact of Presymptomatic

Molecular Testing in Hereditary

Cancers the genes causing many of the inherited cancers means that we can now adopt a more targeted approach to helping each family. Once a family has been identified as having an inherited predisposition to cancer, the causative gene or genes can be screened and the mutation responsible identified. At-risk family members can then be offered a test to determine if they have inherited the defective gene and if they have, they can then continue to be screened clinically and treated at an early stage before the cancer develops. Those who have not inherited the defective gene need no longer be included in the screening programme.

\section{Procedures for Genetic Testing}

Genetic testing for inherited cancers requires appropriate indications and a testing strategy plus provision of both pre- and posttest counselling. For this reason, it is generally

Med Principles Pract 2000;9:221-248 
recommended that testing should be carried out within the structure of a genetics centre where multidisciplinary teams are available to provide both clinical and scientific expertise $[2,3]$. Issues which need to be considered are:

(1) A full family history should be available so that a pedigree can be drawn up. It is often necessary to confirm diagnoses on deceased family members by obtaining pathology reports or obtaining details from cancer registries. It is not unusual to get information from family members regarding deceased relatives which when followed up proves to be incorrect. The accuracy of family information has been studied and shown to be quite variable particularly depending on the type of cancer and the degree of kinship of the affected relative [4].

(2) Families need to be given both the clinical and scientific background to the cancer and should be made aware of all their options. Some families may not want molecular testing and may prefer to remain in a clinical screening programme. In some families, it may not be possible to obtain a mutation result so they should be counselled with this in mind. Counsellors should not be directive when discussing options with patients but should instead be able to provide individuals with all the information which will enable them to make an informed decision on issues.

(3) Families need to be clear about their risks. Attitudes to risk will differ from one family to another, as what one person perceives as high risk may be an acceptable risk to someone else.

(4) Appropriate support should be available both to deliver results of molecular tests and to follow up individuals after testing. Support is often still necessary if an individual gets a negative test. Although the majority of individuals are likely to be happy with a negative result, which puts their own off- spring in the clear, the phenomenon of survivor guilt is also well recognized [3].

Other issues are also important. There are a number of ethical issues which should be considered before predictive testing is carried out. One of these is the age at which testing should be done. In general, testing should not be carried out on children until they are at an age to understand the process and make their own decision as to whether they want the test [5]. Incorporation of a positive result in a child's medical record could for example also lead to problems in later life such as with employment and insurance issues. However, some conditions, such as familial adenomatous polyposis, develop during adolescence, and it may therefore be appropriate to carry out the testing in childhood $[2,6,7]$. In other conditions such as hereditary non-polyposis colon cancer, the majority of individuals do not develop the disease until they are in their 20 s and 30 s, so predictive testing can be delayed until individuals reach adult life. Screening options in some inherited cancers may be straightforward, as in hereditary colon cancers, in which a premalignant lesion can be identified at an early stage and removed or appropriate surgery can be carried out. A more difficult issue to address is how to deal with situations for which clinical screening is not proven, e.g. in Li-Fraumeni syndrome. This condition is associated with a wide spectrum of tumours (see below) for which effective screening is not readily available. In this situation, it may be that individuals may prefer to be aware of their risks so that they can plan their life and make informed decisions about issues such as childbearing even though the available clinical screening may not be able to help them directly. Similarly in familial breast cancer, mammography in premenopausal women is not entirely efficient. In addition it is now clear that the penetrance of some genes such as the BRCA1 and 2 genes 
associated with familial breast and ovarian cancer is not $100 \%$. Women therefore have to be made fully aware of their options before deciding on a treatment such as prophylactic mastectomy [8]. Finally, the option of prenatal diagnosis needs careful consideration for a condition with adult onset and for which treatment such as prophylactic surgery can potentially offer at least a partial cure.

As well as all the clinical considerations, it must be remembered that the knowledge that an individual carries a mutation in a gene, which predisposes him or her to develop cancer, has major implications for the ability to obtain life or health insurance. A survey of members of genetic support groups with a variety of genetic disorders in the family indicated that $25 \%$ of them were refused life insurance, $22 \%$ were refused health insurance and $13 \%$ were denied or lost employment [9]. A survey of insurance companies showed that $10 \%$ would not provide health insurance to HNPCC (hereditary non-polyposis colon cancer) gene carriers and 20\% said that they would increase the premiums. A quarter of insurers would not provide life insurance or would only provide it at increased premiums [10]. Therefore, although there are considerable benefits to offering molecular testing for inherited cancers, there are many issues which should be considered before undertaking such a process.

This review will consider what is currently available for the molecular testing of familial cancer syndromes beginning with a brief description of the molecular methods used for mutation detection.

\section{Methods of Mutation Detection}

The basic strategy for testing for mutations in each of the familial cancer syndromes is similar although the specific methodology may vary. It is complicated by the fact that for each of the genes associated with the familial cancers described in subsequent sections, many different mutations have been described, the majority having been found in only one family with the condition. This makes the situation far more complicated than for genetic diseases, such as sickle cell disease, where all affected individuals carry the same mutation. In addition cancer genes tend to be large and the associated mutations involve only a single or a few bases and hence can be difficult to find.

In each family, DNA from an affected individual should always be tested in the first instance to identify the causative mutation [7]. If there is no living affected individual in a family from whom DNA can be obtained, it may still be feasible to carry out mutation detection if formalin-fixed paraffin blocks of tissue removed at the time of surgery are available from which DNA can be extracted [11]. Unaffected at-risk individuals should not be tested until the mutation is identified since no method of mutation detection is $100 \%$ sensitive. The absence of an identifiable change in an at-risk individual does not therefore necessarily mean that the individual is no longer at risk.

All mutation detection methods are timeconsuming and expensive and there is no single perfect method. Even the gold standard, direct sequencing of the gene, can miss mutations. The specific method chosen to screen for mutations is dependent on a number of variables including (a) sensitivity, (b) budget, (c) hazards associated with chemicals required, (d) technical ease, (e) nature of mutations associated with the disorder and (f) personal experience. Only a brief description of the commonest methods is given here. Full details of them can be found in Langren [12] and Cotton et al. [13]. In general, each of the scanning methods described below entails 


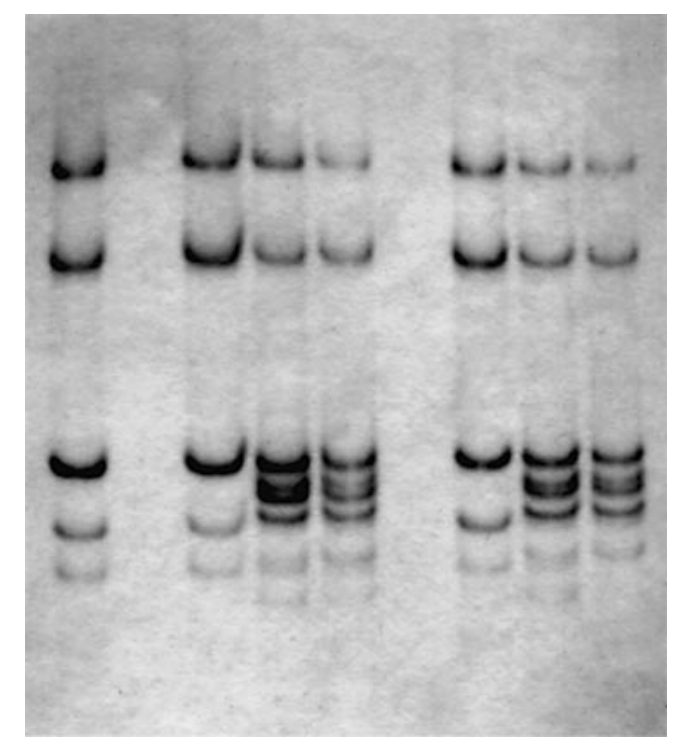

Fig. 1. An example of SSCP of exon of $12 \mathrm{hMSH} 2$. Abnormal bands are seen in lanes 4, 5, 8, 9. Lanes 2 and 6 are blank. All other lanes show a normal pattern. (Courtesy of Yvonne Wallis, West Midlands Regional Genetics Laboratory.)

analysis of a gene, exon by exon, to identify the presence of possible sequence variation. In each case, an exon or fragment of an exon if it is large, is amplified by the polymerase chain reaction (PCR) and the products are then analysed by gel electrophoresis. The exon or exons identified as potentially abnormal are then sequenced.

\section{Single-Stranded Conformation Analysis (SSCP)}

This is a relatively straightforward technique, which is widely used. DNA is firstly amplified by PCR, then denatured to produce single-stranded molecules and electrophoresed through an acrylamide gel, which is subsequently stained - usually by silver staining to visualise the DNA fragments. Alternatively, fluorescently tagged primers can be used at the PCR stage and the fragments are then detected by electrophoresis on an automated sequencer. Even single nucleotide changes are sufficient to influence the secondary structure of a single-stranded piece of DNA, which will in turn alter its migration pattern through the gel. The presence of a sequence variation is therefore detected by the mobility shift of the fragment (fig. 1). As both neutral polymorphisms as well as true mutations will cause such shifts, any fragment of the gene which does show a change must be sequenced to confirm that the alteration is a mutation. The mean advantage of SSCP is its simplicity with relatively low costs. The main drawback of the technique is its limited sensitivity. If the DNA fragment under investigation is relatively short, e.g. less than around $300 \mathrm{bp}$, the sensitivity is good at over $80 \%$. However, the larger the fragment, the lower the sensitivity and in fragments over $500 \mathrm{bp}$ the detection rate can drop below $40 \%$.

\section{Heteroduplex Analysis}

This technique is similar to SSCP but here the DNA fragments are run in doublestranded form. Following PCR, the DNA is denatured, then allowed to reanneal slowly. Two DNA strands derived from two different alleles can reanneal and will result in a molecule which is mismatched at the site of sequence variation. This heteroduplex molecule will migrate differently to the wild type or mutant homoduplex molecules which are perfectly matched, and this can be detected as a mobility shift on the gel. This technique is therefore also very easy to carry out, but as with SSCP it lacks sensitivity. In general, it can detect insertion and deletion mutations with greater sensitivity than point mutations as the mismatched regions are larger.

\section{Denaturing Gradient Gel Electrophoresis (DGGE)}

This technique makes use of the fact that as DNA is electrophoresed through a gradient 
of increasing denaturant, it will eventually become single-stranded. The concentration of denaturant at which this occurs is dependent on the sequence of the DNA. It therefore follows that two DNA species with differing sequence will denature at different concentrations. As a region of the DNA fragment becomes single-stranded and the molecule becomes branched, its migration through the gel is retarded. As with the techniques above, the presence of sequence variation can be identified by a mobility shift in the PCR fragment after the gel has been stained (fig. 2). The major advantage of DGGE is that it is close to $100 \%$ sensitivity. It can, however, be quite time-consuming to establish, as each PCR fragment will melt at a differing range of denaturant and this has to be determined before the technique can be used. It can also be expensive as the PCR primers have a 'socalled' GC clamp - approximately $40 \mathrm{bp}$ of GC sequence - attached to each primer. This region has a very high melting temperature, which will ensure that the PCR fragment will not become completely denatured during its migration through the gel. Should the fragment become completely single-stranded each molecule would migrate at a similar rate and it would be impossible to differentiate mutant from wild-type sequence.

\section{Protein Truncation Test (PTT)}

This test makes use of the fact that many causative mutations in the cancer genes are nonsense mutations, i.e. mutations which result in the replacement of a codon for an amino acid with one for a stop codon. This in turn results in a prematurely truncated protein. The basis of the technique is to carry out an in vitro transcription and translation reaction. DNA is amplified using primers which contain a T7 promoter sequence and a eukaryotic translation initiation sequence. After the PCR reaction, the products can therefore be tran-

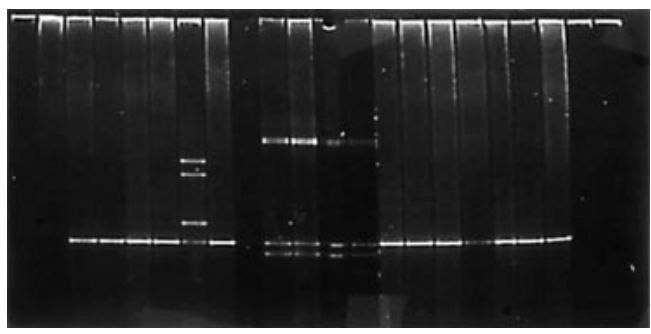

Fig. 2. DGGE analysis of exon 8 of APC. The wildtype homoduplex band is seen in all tracks. Mutant homoduplex bands are seen immediately above (lane 6) or below (lanes 9-12). Heteroduplex bands are seen above the homoduplex bands in lanes 6 and 9-12. Lanes 1 and 8 are blank. (Courtesy of Yvonne Wallis, West Midlands Regional Genetics Laboratory.)

scribed into RNA and subsequently translated into a peptide sequence reflecting part of the protein under investigation. In order to detect the in vitro synthesized peptide, radiolabelled amino acids are included in the translation reaction. The translated products are then resolved on an SDS polyacrylamide gel. The appearance of a shorter than normal peptide indicates the presence of a nonsense mutation (fig. 3). The great advantage of this technique, unlike those above, is that it will only detect true mutations and not polymorphisms. In addition, the initial PCR reaction is carried out over a region of up to $1 \mathrm{~kb}$ instead of a few hundred base pairs. This means, for example, that exon 15 of the APC gene (see below) can be analysed in 4 segments instead of the 23 reactions normally used if analysed by SSCP or DGGE [14]. The disadvantage of PTT is that it cannot detect missense mutations, i.e. mutations which result in the alternative of one amino acid for another, which are causative in some genes, e.g. the VHL gene. In addition, RNA may be needed for the starting material if the target gene contains many small exons interrupted by large stretches of intronic sequence which are hence too large to amplify by PCR. In this 

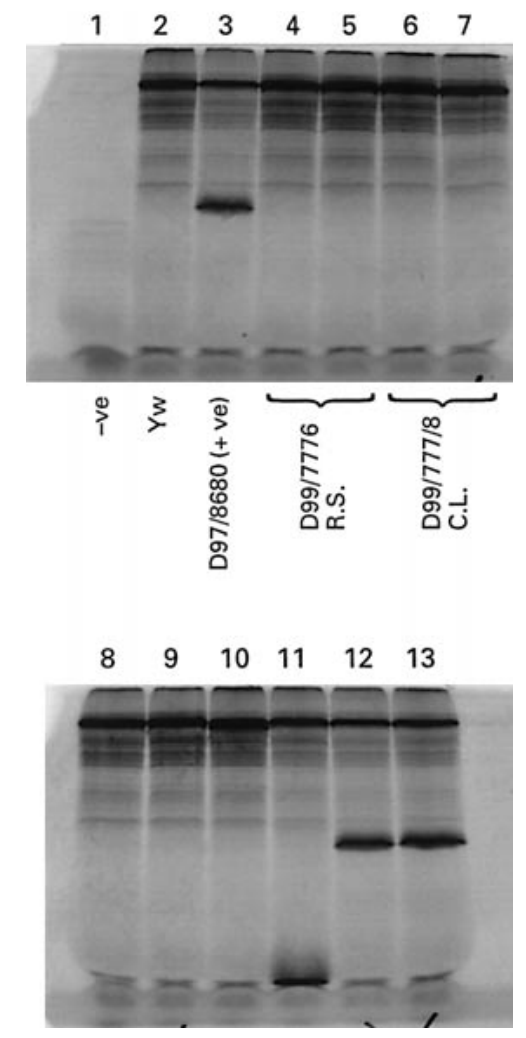

Fig. 3. PTT analysis of exon 15 of APC. Wild-type bands are seen at the top of each gel. Truncated proteins are detected as additional smaller bands in lanes 3, 11, 12 and 13. (Courtesy of Yvonne Wallis, West Midlands Regional Genetics Laboratory.)

situation a cDNA template has to be made from RNA as starting material for the PCR reaction. Only in genes with large uninterrupted regions of coding sequence, e.g. APC, exon 15 or exons 10 and 11 of BRCA1 and BRCA2, can genomic DNA be used as a template.

\section{Direct Sequencing}

Direct sequencing of the genes is perhaps the most sensitive of all methods for detection of mutations. In general, both forward and reverse strands of the gene are sequenced. It is now most commonly carried out according to the dideoxy method of Sanger by PCR using either fluorescently labelled dideoxy chain terminators or primers. The products can then be detected on commercially available DNA sequencers. The obvious advantage of the technique is that it should theoretically pick up all mutations. However, it is possible to miss point mutations present in the heterozygous state. The major disadvantages of the technique are the time-consuming nature of the test, the high cost of the procedure and the availability of considerable time on a sequencer.

\section{Other Techniques}

In addition to the methods described above, RNase protection, bi-dideoxy fingerprinting and chemical cleavage of mismatches have also been used for the detection of mutations in cancer genes. Recently, denaturing high performance liquid chromatography has been introduced into laboratories and shown to be a potentially useful and sensitive alternative to the methods described above.

DNA 'chips' or microarrays are increasingly being developed as an alternative approach to the detection of mutations. These 'chips' consist of microarrays of hundreds to thousands of oligonucleotides fixed onto a glass slide. For detection of mutations in a cancer gene, the oligonucleotides spotted onto the slide correspond to all wild-type and single nucleotide substitution sequences in the gene of interest. The technology then makes use of a hybridisation approach. Target DNA from the patient under investigation is amplified by PCR, fluorescently labelled and hybridised to the oligonucleotides attached to the slide. If the patient's DNA contains a mutation, it will hybridise to the complementary oligonucleotide on the slide and can be detected by fluorescence-based detection methods. This has been trialed with the BRCA1 gene associated 
with familial breast cancer. However, there are still problems with the technology, particularly with respect to its specificity, so the true potential of the technique remains to be realised.

\section{Familial Colon Cancer}

In the USA around 150,000 cases of colorectal cancer are diagnosed each year and it is the cause of death in around 60,000. In the UK, it accounts for around 15,000 deaths per annum and as such, the disease remains a major cause of morbidity and mortality in the Western world. Ten to fifteen percent of cases of colorectal cancer will have a hereditary component. The underlying mechanism in many of these remains unknown, but in recent years it has been well established for two conditions. These are familial adenomatous polyposis (FAP) and hereditary non-polyposis colon cancer (HNPCC), which together account for up to $5 \%$ of cases of colorectal cancer. Mutations in the causative genes for these two diseases place mutation carriers at a lifetime risk of developing colorectal cancer of $80-100 \%$ [15]. Both conditions are inherited in an autosomal dominant manner and thus $50 \%$ of the offspring of an affected parent are at risk of developing the disorder. The identification of the genes responsible for these symptoms means that it is now possible to offer patients presymptomatic diagnosis and assist in the early removal of potentially malignant lesions preventing the development of cancer and the early death of the individual.

\section{Familial Adenomatous Polyposis}

FAP accounts for around $1-2 \%$ of all colorectal cancer. It is characterised by the presence of hundreds to thousands of polyps throughout the colon and rectum and the presence of these features can be used to confirm the diagnosis. Without surgical intervention it is close to $100 \%$ certain that at least one of these polyps will become malignant, usually by the third or fourth decade of life. Until recently, cancer was often already present by the time the patient was investigated and frequently led to the early death of the patient [16]. In addition to the colorectal symptoms a number of extracolonic features are associated with the disease including osteomas, epidermoid cysts, congenital hypertrophy of the retinal pigment epithelium and desmoid tumours. Upper gastrointestinal adenomas are also found as well as hepatoblastomas, periampullary cancers and thyroid cancers [17]. Approximately $20 \%$ of cases of FAP are due to new mutations.

Prevention from early death from colorectal cancer requires reliable screening procedures. The recommended treatment for FAP is generally a total colectomy with ileorectal anastomosis. Subsequent monitoring should then include lifelong surveillance of the rectal stump and regular upper gastrointestinal surveillance. At-risk individuals should be monitored by regular, usually annual, sigmoidoscopy from the early teens until at least 40 years of age [18].

The gene for FAP, the APC gene, was localised to the long arm of chromosome 5 in 1987 [19] and was isolated 4 years later [20,21]. A coding sequence of $8,532 \mathrm{bp}$ was identified divided into 15 coding exons (fig. 4). The first 14 exons are several hundred base pairs whereas exon 15 is unusually long, encompassing $6.5 \mathrm{~kb}$. An additional coding exon known as exon $\mathrm{X}$ or $10 \mathrm{~A}$ was subsequently isolated [22]. The protein encoded by APC has a number of functions including a role in cell adhesion through its association with $\beta$ catenin and subsequent interaction with the cell adhesion molecule E cadherin [23]. APC protein also functions in various signal trans- 


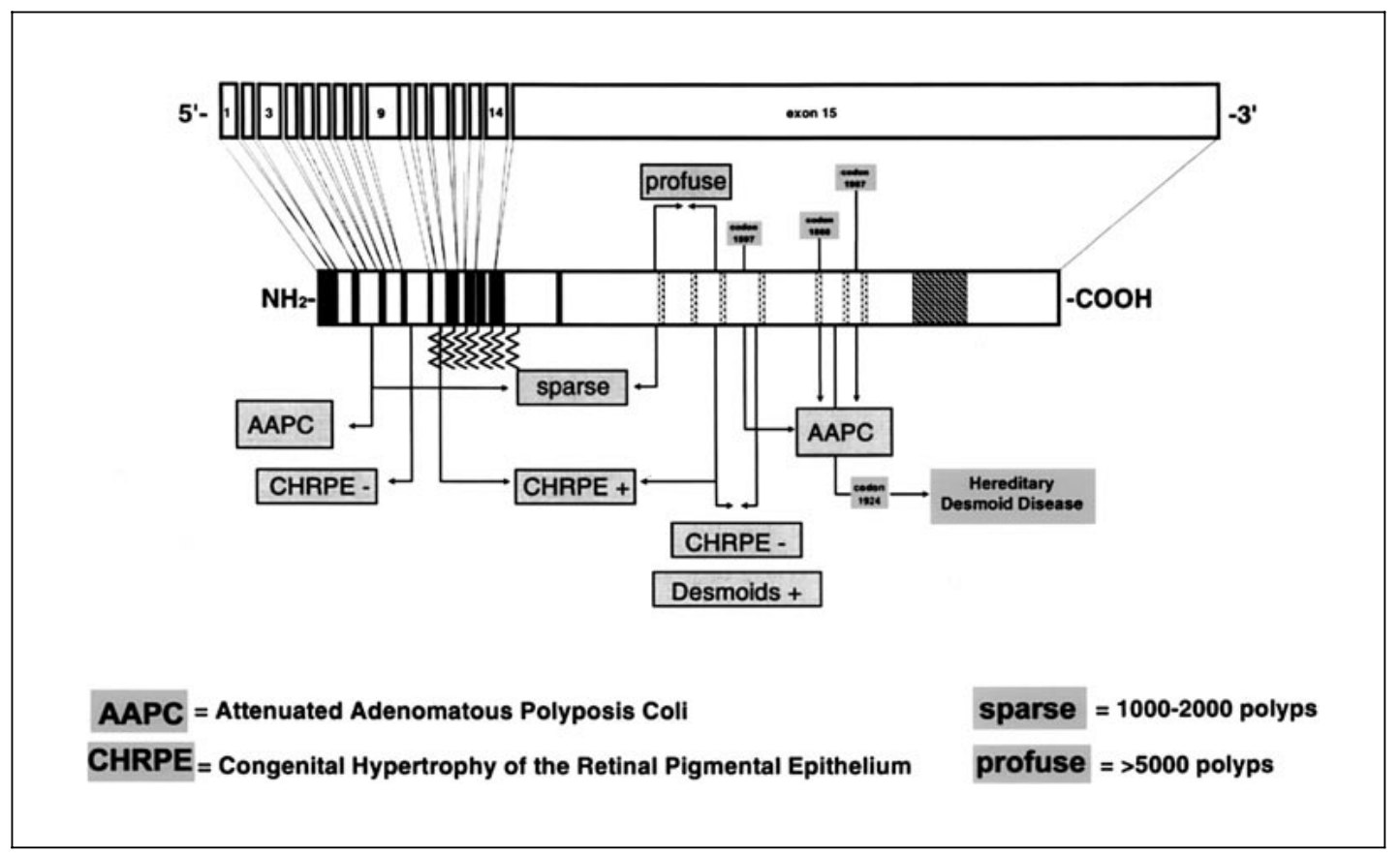

Fig. 4. Structure of the APC gene and APC protein. Genotype-phenotype correlations are indicated. (Reproduced with permission of Dr. R. Fodde and Begell House Publishers.)

duction pathways including the Wnt signalling pathway [24].

The isolation of the gene enabled direct mutation analysis of the families to be carried out. Many mutations have so far been identified $[25,26]$ and are spread throughout the coding region of APC. The vast majority, $>99 \%$, of mutations are truncating mutations caused either by point mutations or small insertions or deletions. No missense mutation has as yet clearly been shown to be the cause of the disease although some have been implicated as predisposing to colon cancer [27, 28]. The majority of mutations have only been seen in a single family. However, two mutations have been found world-wide and account for up to $10 \%$ of cases of FAP. These are both 5-bp deletions at codon 1061 and codon 1309. (A database of APC mutations can be found at http://perso.curie.fr/Thierry.Soussi/APC.html.)

Mutation analysis of DNA from an affected individual normally depends on the use of a technique such as SSCP or DGGE to study the first 14 small exons and PTT is most commonly used to study exon 15 in four overlapping fragments. The two common mutations can be screened for initially by direct PCR [25]. Even if affected individuals are deceased, it is still possible to obtain mutation results, as DNA extracted from tumour blocks has been shown to be suitable for PCR analysis [11]. A germ line mutation has been identified in $20-90 \%$ of FAP patients in published studies [25, 26, 29]. The variation in pick-up rates reflects the extent to which the gene has been analysed and the technique used. It is also likely to reflect the accuracy of the clini- 
cal diagnosis of the patient referred, as, although the majority of cases can be confirmed by the histological appearance of the colon, there is some variation in phenotype both in number of polyps, age at onset of the disease and presence of extracolonic features.

Several studies have examined genotypephenotype correlations in APC (fig. 4) [25, 30, $31]$. An early association was made between the position of mutation and the presence or absence of congenital hypertrophy of the retinal pigment epithelium [30, 32]. Desmoid tumours are primarily, although not solely, associated with mutations at the $3^{\prime}$ end of the gene [33, 34]. Mutations from codons 1250 to 1464 have been associated with a profuse phenotype with more than 5,000 polyps present [35] and the commonly seen mutation at codon 1309 is associated with a severe phenotype [36]. Attenuated FAP is associated with mutations near the $5^{\prime}$ end of the gene [37]. However, these findings are not absolute, and so cannot be used to predict the phenotype in patients with any certainty. For example, a particularly severe phenotype has been seen in two families with mutations in exon 11. In these families, affected individuals were diagnosed as young as 5 years of age and cancer was detected in 1 individual aged 9 [7]. The presence of extracolonic manifestations can be used, however, to indicate where to look initially for mutations [30]. The complex relationship between genotype and phenotype is made even more complex by the identification of possible modifiers of the phenotype. Modifier loci in FAP were first identified by investigation of the MIN mouse - a mouse which develops multiple intestinal polyps and which has truncating mutations in APC [38]. A candidate gene for the modifier has been proposed to be the secreted form of phospholipase A2, which is found on chromosome $1 \mathrm{p}$ in humans [39].

The Impact of Presymptomatic

Molecular Testing in Hereditary

Cancers

\section{Hereditary Non-Polyposis Colon Cancer}

HNPCC is more common than FAP, accouting for $3-5 \%$ of colorectal cancer. It is subdivided into three clinical forms called Lynch type 1, Lynch type 2 and Muir-Torre syndromes. As with FAP, it is associated with colorectal cancer, but in this condition the mean age at onset is later than in FAP at around 45 years of age. The lifetime risk of developing colorectal cancer in gene carriers is around $80 \%$. Other features include (1) predominantly right-sided tumours, (2) the presence of synchronous and metachronous tumours, (3) tumours with poor differentiation and (4) tumours which behave rather more indolently than other colorectal cancers [40]. In Lynch type 2 syndrome as well as colorectal cancer, there is an increased risk of other cancers such as endometrial, ovarian, stomach, small bowel and hepatobiliary cancers as well as transitional cell tumours of the renal pelvis and ureter. In Muir-Torre syndrome all of these cancers are found along with sebaceous adenomas, carcinomas and keratoacanthomas (fig. 5). Treatment for HNPCC-affected individuals is generally subtotal colectomy with ileorectal anastomosis or hemicolectomy with surveillance of the remaining bowel. Because of the high risk of endometrial cancer, prophylactic hysterectomy has been proposed once an individual's family is complete. The alternative is regular pelvic ultrasound. Atrisk individuals require colonoscopy from 20-25 years of age at 2- to 3-yearly intervals and ultrasound screening of women at risk should also be offered [41].

Unlike FAP, HNPCC cannot be distinguished purely on clinical features. It was originally defined by a series of criteria termed the Amsterdam criteria, which were described to facilitate research before the isolation of the causative gene [42]. These criteria are (1) histologically verified colorectal cancer in at least 3 family members, 1 of

Med Principles Pract 2000;9:221-248 


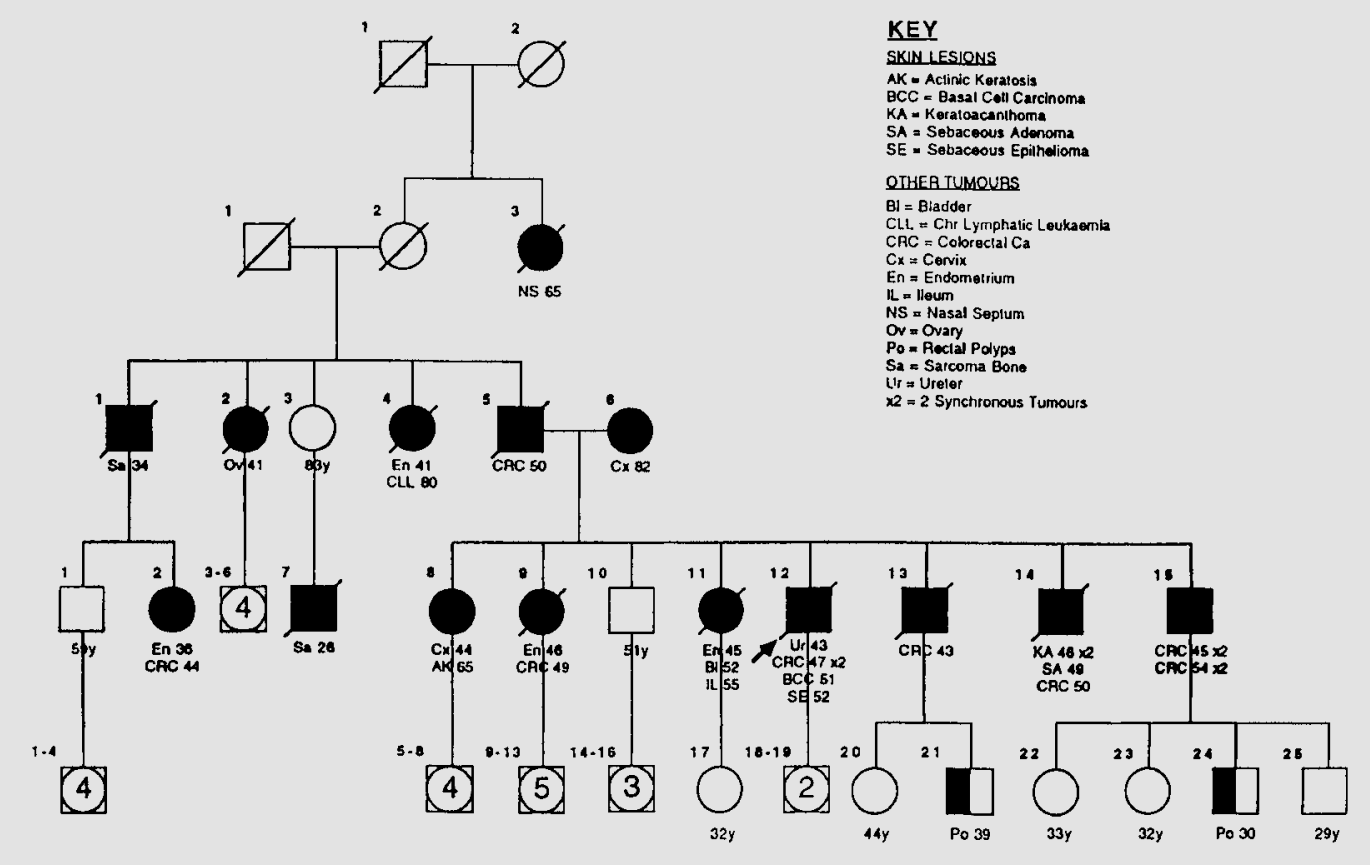

Fig. 5. Pedigree of a family with the Muir-Torre variant of HNPCC indicating the variety of tumours seen in affected individuals. Males are shown as squares and females as circles. Affected individuals are indicated by filled-in symbols. Deceased individuals are indicated by a line through the symbol.

whom is a first-degree relative of another, (2) 1 individual must have been diagnosed under 50 years of age, (3) colorectal cancer should involve at least two generations and (4) FAP must have been excluded. However, the Amsterdam criteria do not take into account other features of the disease, such as extracolonic cancers, and are now generally considered too strict for assessing families suitable for molecular testing now that the genes have been identified. These less strict criteria are termed the Bethesda criteria [43] and include characteristics reported in HNPCC as shown in table 2.

A gene for HNPCC was mapped to chromosome $2 p$ in two large kindreds following a genome-wide search with 345 microsatellite markers [44]. At that time it was clear that there was genetic heterogeneity and indeed within a few months a further family was shown to be linked to a gene on chromosome $3 p$ [45]. The majority of families with HNPCC were believed to be linked to either chromosome $2 p$ or $3 p$, but at least one family was shown to map to neither locus.

At the same time as linkage studies to map the genes were ongoing, further studies were identifying a surprising phenomenon. When the DNA from tumours was analysed by PCR amplification of microsatellite markers alongside DNA from normal tissue from the same patient, shifts in the electrophoretic mobility 


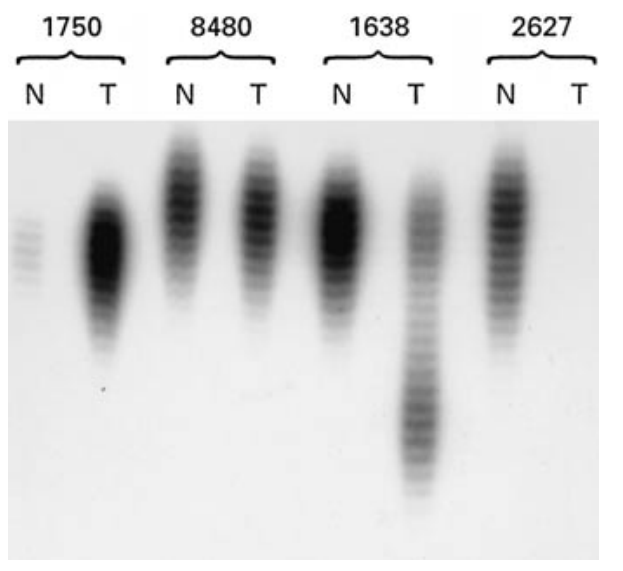

Fig. 6. Example of microsatellite instability using the BAT 40 marker. For each patient the left-hand lane shows the result obtained using DNA from normal tissue $(\mathrm{N})$ whereas the right-hand lane shows the result from tumour DNA (T). Patient 1638 shows microsatellite instability in the tumour. (Courtesy of Prof. E. Maher, Division of Molecular and Medical Genetics, Department of Paediatrics, University of Birmingham.)

Table 2. Bethesda criteria for the diagnosis of HNPCC

1 Individuals with cancers in families that meet the Amsterdam criteria

2 Individuals with two HNPCC-related cancers, including synchronous and metachronous cancers or associated extracolonic cancers

3 Individuals with colorectal cancer and a firstdegree relative with colorectal and/or HNPCCrelated cancers and/or a colorectal adenoma; one of the cancers diagnosed $<45$ years and the adenoma diagnosed $<40$ years

4 Individuals with colorectal cancer or endometrial cancer diagnosed at age $<45$ years

5 Individuals with right-sided colorectal cancer with an undifferentiated pattern on histopathology diagnosed at age $<45$ years

6 Individuals with signet ring cell type colorectal cancer diagnosed $<45$ years

7 Individuals with adenomas diagnosed at age $<40$ years

The Impact of Presymptomatic

Molecular Testing in Hereditary

Cancers of the markers were seen (fig. 6). These shifts can be seen as the presence of additional bands in the tumour DNA. This was taken to mean that there was genomic instability manifesting as errors in the replication of DNA in the tumours [46]. The phenomenon was termed replication errors or microsatellite instability (MSI). MSI has been identified in nearly all the tumours of patients with HNPCC both colorectal and extracolonic, but has also been seen in $10-15 \%$ of sporadic colorectal cancers [47]. MSI had previously been identified in micro-organisms, both $E s$ cherichia coli and Saccharomyces cerevisiae, and this was known to be due to defects in the proteins of the mismatch repair pathway [48] (table 3). These proteins function by increasing the fidelity of replication by repair of DNA polymerase misincorporation errors. It was therefore hypothesized that there might be human homologues of the bacterial/yeast mismatch repair proteins, which when mutated gave rise to the replication errors seen in the tumours and might therefore be the genes associated with HNPCC. The human homologue of the E. coli gene, mutS, was mapped to chromosome $2 p$ [49] and identification of mutations in this gene, called hMSH2, in kindreds with HNPCC confirmed that it was one of the causative genes. Mutations in the human homologue of the mutL gene, hMLH1, were identified shortly after [50]. Three more human mismatch repair genes, hPMS1, hPMS2 and hMSH6 or GTBP, all of which are mutated in some HNPCC families, were subsequently identified [51, 52]. Table 3 gives details of these mismatch repair (MMR) genes.

hMSH 2 and hMLH 1 account for over $90 \%$ of cases of HNPCC and so together are the two genes which are screened routinely in diagnostic laboratories using the mutation detection methods described above [53, 54]. Details of mutations identified can be found 
Table 3. Mismatch repair genes associated with HNPCC and their relationship to yeast and bacteria

\begin{tabular}{lllll}
\hline Gene & E.coli & S. cerevisiae & cDNA, bp & Location \\
\hline hMSH2 & mutS & MSH2 & 3,111 & $2 \mathrm{p} 16$ \\
hMLH1 & mutL & MLH1 & 4,244 & $2 \mathrm{p} 16$ \\
hPMS1 & mutL & PMS1 & 2,484 & $3 \mathrm{p} 21-23$ \\
hPMS2 & mutL & PMS1 & 3,063 & $2 \mathrm{q} 31-33$ \\
hMSH6 & mutS & MSH2 & 2,771 & $7 \mathrm{q} 22$ \\
\hline
\end{tabular}

on the HNPCC mutation database (www. nfdht.nl). There are no common mutations as such in HNPCC, but a number of founder mutations have been recognised particularly in Finland [55, 56] and in Newfoundland [57].

As with FAP, the identification of causative mutations allows for the provision of presymptomatic testing of those individuals at risk. It can be more complicated than that for APC as both nonsense and missense mutations have been identified in both genes. The latter are problematic as it can be difficult to confirm that a change in an amino acid sequence is truly the cause of the disease. The presence of the change in all affected members of the pedigree, a significant alteration in the properties of the wild-type and mutant amino acid, e.g. a hydrophobic substituted for a hydrophilic amino acid, and the degree of conservation of the amino acid in other species can all help to indicate that the change is significant. However, to be certain of the role of the mutation, functional assays are required [58] and these tend to be used primarily in research laboratories. Missense mutations may therefore remain unusable for presymptomatic diagnosis.

Several studies have tried to develop a rational, efficient and reasonably cost-effective strategy to screen for MMR mutations given the lack of a clear clinical diagnosis, the involvement of several genes and the lack of genotype-phenotype correlations as described below. The ultimate goal is to have maximum sensitivity, i.e. as few false negatives as possible along with the maximum specificity. Aaltonen et al. [59] used microsatellite instability as a preliminary screening test of a panel of 509 patients with colorectal cancer. Of the 63 who were positive, 10 had a germ line MMR mutation, thus emphasising the value of MSI as a pre-screen. Wijnen et al. [60] have shown that a younger age at diagnosis, fulfilment of the Amsterdam criteria and the presence of endometrial cancer in the kindred are independent prognosticators of germ line mutations in hMSH2 or hMLH1. They used these to develop a logistic model for estimating the likelihood of a mutation in either gene. Loukola et al. [61] have suggested that a consolidation of these two strategies, i.e. combination of family information plus the presence of MSI, should be considered. The Bethesda criteria described in table 2 were suggested as a method to identify those individuals who should initially be tested for MSI. Those which were positive could then go on to mutation screening [43]. A second study has also shown that adherence to the strict Amsterdam criteria for mutation testing will also miss a number of patients with germ line mutations [62]. Again, a combination of MSI analysis and modified family history criteria was advocated to predict those most likely to have a germ line mutation.

Unlike FAP, there are no very clear genotype-phenotype correlations in HNPCC. Some loose associations have however been made. There is an increased risk of extracolonic cancers in individuals with hMSH2 mutations compared to hMLH1 mutations [63]. hMSH6 mutations have been associated with an atypical phenotype occurring in smaller pedigrees and associated with a later age of onset, a predominance of extracolonic cancers 
and a lower incidence of microsatellite instability [52].

An important feature of HNPCC when counselling patients following mutation detection is the incomplete penetrance of the phenotype. Inheritance of a hMSH2 or hMLH1 mutation is associated with an $80 \%$ risk of developing colorectal cancer by the age of 80 [63]. Female members of such families have a $40-50 \%$ risk of endometrial cancer. The risk of developing ovarian cancer. The risk of developing ovarian cancer is approximately $9 \%$. In at least one study, considerable differences were shown for the risk of developing colorectal cancer depending on the sex of the individual [15]. Females had a much lower risk of colorectal cancer, $30 \%$ compared to $74 \%$ for males, and in fact the risk of endometrial cancer in females was higher than that for colorectal cancer.

\section{Procedures and Consequences of Genetic Testing for Colorectal Cancers}

Screening of patients at risk of colorectal cancer, both clinically and by molecular testing, can clearly prevent the early death of the individual. This is best done by the establishment of a genetic register and the benefits of such a process have been demonstrated for FAP $[6,16]$. As mentioned at the beginning of this review, molecular testing of cancer families is ideally performed within the context of genetic centres to provide pre-test counselling and correct interpretation of tests [2]. Studies have shown that this approach has not always been used particularly with respect to pre-test counselling [64].

The effectiveness of various treatment strategies including the use of non-steroidal anti-inflammatory drugs such as sulindac or even aspirin is now under investigation in individuals proven to be APC mutation carriers with a view to try to prevent or slow down the development of polyps [65]. A study
Table 4. Clinical syndromes associated with breast cancer

Site-specific breast cancer

Breast/ovarian cancer

Cowden's disease

Lynch type 2 syndrome

Li-Fraumeni syndrome

Peutz-Jeghers syndrome

Klinefelter syndrome

has shown that the MSI in colorectal cells with an MMR defect is considerably reduced following exposure to sulindac or aspirin [66].

Finally, the cost benefits of genetic testing have also been demonstrated for FAP [67]. Costs of mutation analysis are up to $£ 750$ in the UK and up to $\$ 1,300$ in the US. Costs of conventional screening by flexible sigmoidoscopy in the absence of genetic testing are around $\$ 3,200$. Clearly genotyping can reduce the costs of screening and the larger the pedigree and the more at-risk individuals, the greater the cost advantage.

\section{Familial Breast and Breast/Ovarian Cancer}

Approximately 1 in 8 to 1 in 12 women will develop breast cancer and around 5\% of all cases are due to an inherited predisposition. The autosomal dominant nature of breast cancer in some families has been recognised for over 100 years. In women under 35 years of age, inherited breast cancer accounts for around $35 \%$ of cases, although it accounts for $<1 \%$ of cases diagnosed over 80 years of age. The syndromes associated with inherited breast cancer are shown in table 4 . This section will deal primarily with the two major genes contributing to familial breast and breast/ovarian cancer, namely BRCA1 and BRCA2. 
Guidelines for referral and screening in breast cancer families with varying numbers of affected relatives have recently been published [8]. As with other familial cancers, a detailed family history should be obtained and appropriate counselling given before any molecular testing is offered. It is perhaps even more important that this is done for breast cancer than for colorectal cancer given the complex nature of the mutations as described below and the lack of such clear-cut screening methods compared with sigmoidoscopy and colonoscopy.

A gene for familial breast cancer was initially mapped to chromosome 17 in 1990 and was termed BRCA1 [68]. An early study indicated the presence of heterogeneity by demonstrating that the majority of families with breast and ovarian cancer were likely to be caused by this gene, whereas only a proportion of families with breast cancer alone were likely to be caused by BRCA1 [69]. The BRCA1 gene was isolated in 1994 [70] and shown to comprise 24 exons with little homology to other known proteins. Germ line mutations have been identified throughout the gene and over 300 are listed on the breast cancer information core (BIC) database (www . nhgri .nih.gov/Intramural_research/ Lab_transfer/Bic/). In 1994, BRCA2 was mapped to chromosome 13 [71] and was isolated a year later [72]. The gene contains 27 exons. Again a large number of mutations have been identified throughout the gene and are also listed on the BIC database. Existing evidence suggests that at least one or more genes with similar effects to BRCA1 and 2 remain to be detected.

Several approaches have been used to detect mutations in BRCA1 and 2. As the genes are large, it is theoretically necessary to scan 5,283 codons. DNA sequencing is possible and is used in the commercial setting. Most diagnostic laboratories carry out a cascade system of mutation screening. Regions of the genes in which mutations are clustered are screened first. A multiplex heteroduplex analysis has been developed covering 4 regions of BRCA1 in which $24 \%$ of mutations can be found [73]. Following this, exon 11 of BRCA1 and exons 10 and 11 of BRCA2 can be analysed using PTT [74]. Together these tests would be expected to detect around $50 \%$ of all mutations in BRCA1 and 2. Further screening of both genes can then be carried out usually by SSCP or DGGE. Once a mutation is identified, presymptomatic testing is possible for at-risk family members (fig. 7). As with other cancers, mutation analysis is possible using DNA extracted from formalin-fixed paraffin-embedded material, but care must be taken when using this approach as anomalous results have been encountered. Although some BRCA1 and 2 mutations listed in the database have been seen on more than one occasion (including founder mutations described below), most are private. In both genes, nonsense and missense mutations have been identified, the latter being problematic as it can be difficult to prove that they are truly causative as was described above for HNPCC.

In genetically isolated populations, a number of founder mutations have been found. In the Ashkenazi Jewish population, one mutation, $185 \mathrm{delAG}$, has been found in $20 \%$ of women with early onset breast cancer and has a carrier frequency of $0.9 \%$ in the Ashkenazi population [75]. This is in contrast to the general population where the prevalence of all BRCA 1 mutations is around $0.2 \%$. Further studies have identified two other common mutations in the Ashkenazi population. 5382insC in BRCA1 was found at a carrier frequency of $0.13 \%$ and $6174 d$ delT in BRCA2 was found at a carrier frequency of $1.52 \%$ [76]. In total, $60 \%$ of Ashkenazi Jewish women with early onset ovarian cancer and 30\% 


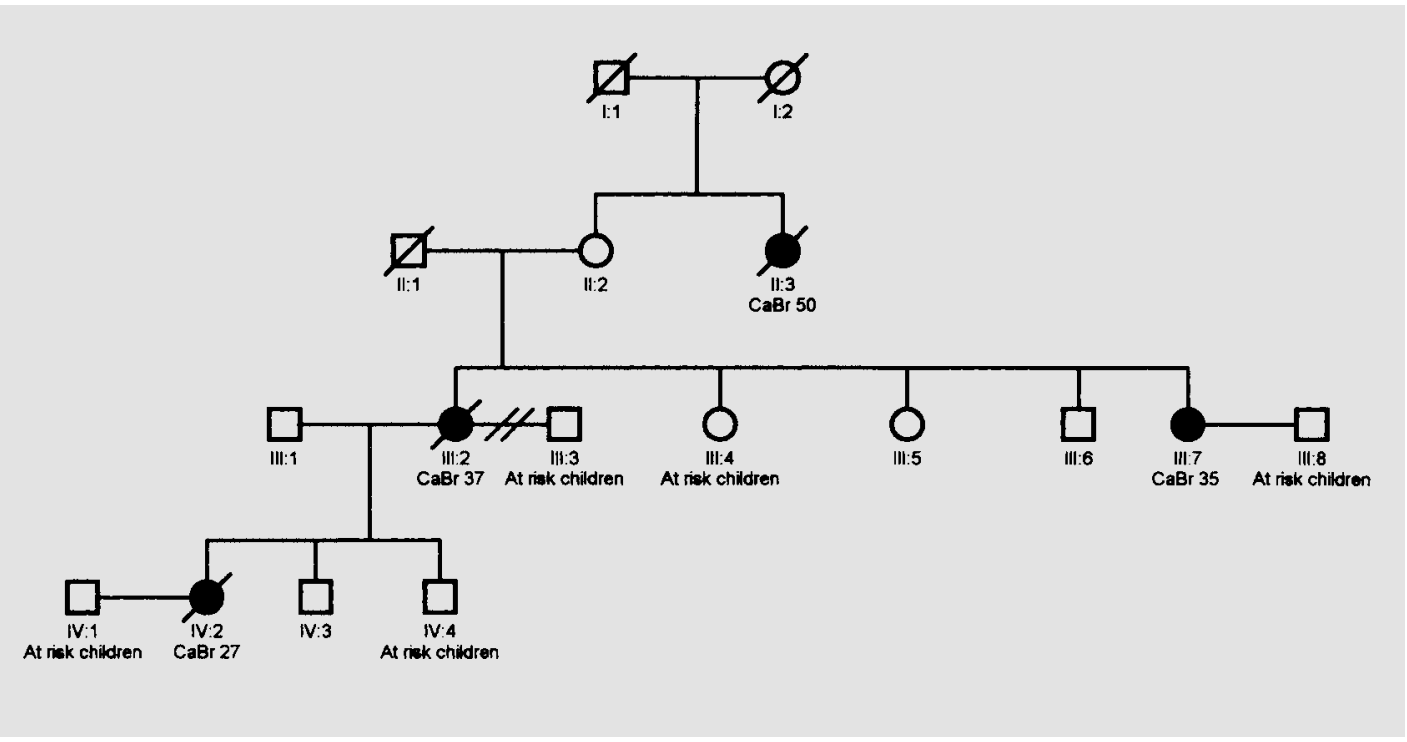

Fig. 7. Pedigree of a family with breast cancer. Individual II-3 developed breast cancer at age 50, III-2 had breast cancer at 37 years, III-7 at 35 years and IV-2 at 27 years. At-risk offspring of the affected individuals can be offered presymptomatic testing once the causative mutation is identified. No evidence of breast cancer has been detected in individual II-2, indicating the non-penetrant nature of BRCA mutations.

with early onset breast cancer carry one of these three mutations [77]. Given the frequency of these mutations in the Ashkenazi population, it is not surprising that double heterozygotes have also been found. 995del5 in BRCA2 has been shown to be a founder mutation in the Icelandic population where, in addition to female breast cancer, it also accounts for $40 \%$ of male breast cancer detected over the last 40 years [78]. Two BRCA1 genomic deletions comprising $36 \%$ of all families with a BRCA1 mutation have been shown to be founder mutations in the Dutch population [79]. Two mutations, C4446T in BRCA1 and 8765 delAG have been identified as founder mutations in the French Canadian population [80]. From these studies it can be seen that it may be important to know the ethnic origins whenever possible if carrying out mutation detection in familial breast cancer.
Some genotype-phenotype correlations have been described in BRCA1 and 2, which can help with the detection of mutations. However, as they are by no means absolute, they should not be used for genetic counselling purposes. In general, the presence of ovarian cancer is more likely to indicate the presence of a BRCA1 mutation. Within BRCA1, mutations in the $3^{\prime}$ end of the gene are associated with a lower risk of ovarian cancer [81]. If ovarian cancer is seen in BRCA2 families, the causative mutations are clustered in a 3.3$\mathrm{kb}$ region of exon 11 bordered by nucleotides 3035 and 6629 [82]. Male breast cancer is generally associated with BRCA2 mutations [83]. Pancreatic, laryngeal and prostate cancer have also been associated with BRCA2 mutations [84].

Counselling for those at risk of familial breast cancer is particularly difficult because 
of the reduced penetrance of BRCA1 and 2 mutations and the reduced efficacy of clinical screening. Risks of developing breast cancer for carriers of a BRCA1 mutation have been calculated to be $51 \%$ by age 50 , rising to $85 \%$ by 70 years of age. The risk of ovarian cancer for BRCA 1 carriers is approximately $30 \%$ by age 60 [85]. The risk of breast cancer for carriers of a BRCA2 mutation is $60 \%$ by age 50 and $71 \%$ by age $60[83,84]$. The risk of male breast cancer for BRCA2 carriers is $6.3 \%$ by age 70 . Female carriers of BRCA mutations have been identified who remain healthy with no evidence of cancer over 80 years of age. This information needs to be made clearly available to patients undergoing predictive testing and who may be considering prophylactic mastectomy.

There are many benefits to families from testing for BRCA mutations, but there are also drawbacks. Once a high-risk family has been referred to a genetic clinic it should be made aware to them that it might not be possible to identify a mutation. There are a number of causes for this including (a) lack of a DNA sample from an affected individual - at the present time mutation screening of unaffected at-risk individuals is not recommended [6], (b) only two genes have been isolated which are screened for mutations, so a highrisk family may have a mutation in an as yet unidentified gene, (c) mutation detection is not $100 \%$ sensitive. Once mutations are found, predictive tests are offered and results given back to patients, there remain difficult choices for the patient including screening options, preventative surgery such as prophylactic mastectomy and oophorectomy or chemoprevention. Follow-up of patients and the availability of psychological support are therefore important. Several psychological studies of the benefits of molecular testing in breast cancer are currently under way in the UK. It must also be remembered that there are significant cost benefits if mutations can be identified in high-risk families. The cost of a molecular test to identify a mutation is around $£ 500-700$ in the diagnostic setting and $\$ 2,500$ in the commercial setting. The costs of predictive testing are then around $£ 100$ per person. This is minimal compared to the cost of regular MRI surveillance of women at risk of inherited breast cancer.

\section{Multiple Endocrine Neoplasia}

\section{Multiple Endocrine Neoplasia Type 1 \\ (MEN-1)}

MEN-1 is an autosomal dominant condition associated with malignancies of the endocrine tissues including the parathyroids, the endocrine pancreas and the anterior pituitary. There is considerable inter- and intrafamilial variation in the phenotype. The age-related penetrance of the disease is $100 \%$ by age 60 [86]. Biochemical screening can detect disease approximately 10 years before patients are symptomatic. Screening of at-risk individuals is important as many of the complications of the condition can be treated. This should begin around 10 years of age and be continued at 5-yearly intervals and include measurement of serum calcium levels, parathyroid hormone levels, pituitary hormone levels, and pancreatic hormones as well as routine clinical investigations. Treatment for tumours is normally surgical.

The gene was initially mapped to chromosome $11 \mathrm{q} 13$ [87]. It took a further 9 years before the gene was eventually isolated [88] and shown to have 10 exons. It encodes a 610amino acid protein called menin. Mutations have been found in exons 2-10 (exon 1 being non-coding) and are primarily nonsense mutations or insertions and deletions predicted to produce a truncated protein resulting in the loss of function of menin [86, 89]. The exact 
role of missense changes remains to be clarified [90]. Germ line mutations have been found in most cases of familial MEN1 as well as the majority of sporadic cases. At the present time there are no genotype-phenotype correlations. Once individuals have been identified as gene carriers, clinical and biochemical evaluation can be commenced after the age of 5 years as described [91]. This will enable early detection of tumours and thereby allow appropriate management of the patient.

\section{Multiple Endocrine Neoplasia Type 2 (MEN-2)}

MEN2 is characterized by the presence of medullary thyroid cancer (MTC) in association with phaeochromocytoma. There are three clinical variants, MEN2A, MEN2B and familial medullary thyroid cancer (FMTC). MEN2A is the most common variant and is associated with phaechromocytoma and parathyroid tumours as well as MTC. In MEN2B, parathyoid involvement is rare. FMTC is characterised by the presence of MTC alone [92]. All forms may be inherited as an autosomal dominant disorder, but may also occur sporadically. Tumours associated with the disorders can be detected by biochemical screening and this can result in diagnosis and hence reduce morbidity and mortality. Screening depends on the measurement of plasma calcitonin in both the basal state and following pentagastrin or calcium stimulation and should be carried out from 1 year of age until at least 30 years [92]. The test, however, is unpleasant and false positives do arise. Clarification of the status of at-risk individuals can be difficult so the use of a DNA test to identify gene carriers is still valuable.

The gene for MEN2 was mapped to the pericentromeric region of chromosome 10 in 1987 [93] and initially it was assumed that the gene responsible would be a tumour suppres- sor gene as is the case for the majority of other familial cancer syndromes. However, the candidate gene based on genetic and physical mapping studies was the RET gene, which is a transforming oncogene. Several laboratories investigated RET and identified mutations in cases of MEN2A, 2B and FMTC [94, 95]. In MEN2A, mutations in 5 cysteine residues of the extracellular domain of RET were found in $93 \%$ of cases, with mutations at codon 634 being present in $83 \%[94,96]$. A strong genotype-phenotype correlation was found between the mutation at codon 634, particularly a cysteine-to-arginine change, and the presence of phaeochromocytoma [96]. A single missense mutation at codon 918 in which methionine is replaced by threonine is found in over $90 \%$ of cases of MEN2B. FMTC is associated with the same spread of mutations as in MEN2A, but the incidence of mutations is more evenly spread across the five cysteines. In all three conditions, the effect of the mutations is to confer a gain of function to the protein. However, the mutations achieve their effects by different mechanisms as would be expected from the differences in the phenotype between the three disorders [97]. Interestingly, a loss of function mutation is also seen in RET in which the gene is inactivated or there is abrogation of the function of the RET protein. These mutations cause a completely unrelated disorder, Hirschsprung's disease, in which there is an abnormality of the hindgut characterised by the absence of enteric autonomic ganglia [98].

\section{Other Familial Cancer Syndromes}

\section{Von Hippel-Lindau Disease (VHL)}

This is an autosomal dominant disorder with an incidence of around 1 in 35,000 [99]. It is associated with a wide variety of tumours including retinal angiomas, cerebellar, spinal 
cord and brain stem haemangioblastomas, renal cell carcinoma and phaeochromocytoma [99]. The penetrance of the disease is around $90 \%$ by 60 years of age. Systematic screening and early detection of tumours have been shown to reduce morbidity and mortality [100]. Screening of both affected and at-risk individuals is fairly intensive involving annual examinations, direct and indirect ophthalmoscopy, MRI scans at 3-yearly intervals, annual renal ultrasound scans and annual 24hour urine collectin for VMA's [100].

The gene for VHL was localised to $3 \mathrm{p} 25-$ 26 [101, 102] and isolated in 1993 [103]. This enabled presymptomatic diagnosis of at-risk individuals and removal of those at negligible risk from the intensive screening otherwise necessary. The gene is relatively small compared with many of the others described above, with only 3 exons encoding a 213-amino acid protein. The identification of at least five VHL binding proteins has led to a clearer understanding of the function of VHL itself [104]. The VHL protein (a) regulates the rate of transcription elongation by binding to elongin $\mathrm{B}$ and $\mathrm{C}$, (b) down-regulates expression of vascular endothelial growth factor mRNA, (c) binds to CUL2, a member of the cullin binding proteins which are believed to target certain proteins for ubiquitination and degradation, (d) is involved in cell cycle control and finally (e) is involved in fibronectin metabolism [104].

Over 150 mutations have been identified in VHL in all three exons. Approximately $60 \%$ of mutations are nonsense and missense mutations whereas the remainder are whole gene or partial gene deletions [105-108]. A combination of direct sequencing with or without SSCP for detection of nonsense and missense mutations plus either Southern blotting or quantitative fluorescent PCR is capable of detecting close to $100 \%$ of mutations [108, plus personal communications]. Many mutations identified are different in different families. Founder mutations in VHL are uncommon but there are a small number of recurring mutations [105-107].

Some genotype-phenotype correlations do exist. A major phenotypic difference between VHL families is the presence or absence of phaeochromocytomas. Nearly all families without phaeochromocytomas have deletions or nonsense mutations. The presence of phaeochromocytomas is associated in $>90 \%$ of cases with missense mutations [106, 107]. In particular a missense mutation occurring at codon 238 (renumbered as codon 167 in later papers) has been identified in $43 \%$ of these families. This finding suggests that a mutant protein must be full length to produce phaeochromocytomas. Mutation-specific counselling, however, still has to be guarded as the total number of cases identified remains small.

\section{Li-Fraumeni Syndrome}

This is a rare autosomal dominant condition characterised by the presence of a range of tumours including breast cancer, brain tumours, soft tissue sarcomas, osteosarcomas, leukaemias and adrenocortical tumours [109]. The condition is defined by very strict clinical criteria [110], but a group of families with a Li-Fraumeni-like condition have also been described [111]. More than $90 \%$ of gene carriers are expected to develop tumours by age 70 [112]. It is caused by mutations in the tumour suppressor gene TP53. Mutations are located primarily in exons 5-8, although they have also been found in other exons [113]. Mutations in TP53 have been found in 70\% of all families with Li-Fraumeni syndrome and $20 \%$ of Li-Fraumeni-like families when the entire gene including non-coding regions is sequenced [113]. Although identification of mutations in TP53 allows presymptomatic diagnosis to be offered to at-risk relatives, the 
lack of effective screening for the majority of associated tumours make testing for this condition very complex and ethically difficult.

\section{Neurofibromatosis}

The neurofibromatoses are a group of neurocutaneous syndromes affecting tissues derived from the neural crest. Two clinically distinct forms have been recognised: neurofibromatosis type 1 (NF1) and neurofibromatosis type 2 (NF2).

NF1 is a common autosomal disorder affecting 1 in 3,000 to 1 in 5,000 people. It is characterised by multiple café au lait spots, neurofibromas and Lisch nodules of the iris [114]. Malignancies including optic gliomas, neurofibrosarcomas, brain gliomas, phaeochromocytomas and leukaemias are seen, but are less commmon complications of the disorder. There is a very wide variation in expression of the disease. The gene was mapped to chromosome 17 in 1987 and cloned 3 years later [115]. Mutation analysis has proved very difficult, although over 100 mutations have now been identified, the majority of which are expected to cause truncations of the protein product, neurofibromin [116]. The demand for molecular testing is relatively low for two reasons. The majority of cases of NF1 can be established on clinical criteria even in early childhood, so presymptomatic diagnosis on molecular grounds is not a very high priority. As the phenotype is highly variable and mutation analysis cannot be used to predict the severity of the disease, prenatal diagnosis is rarely taken up [116].

$N F 2$ is an autosomal dominant disorder with an incidence of approximately 1 in 40,000 and is characterised by the presence of bilateral acoustic neuromas. There is also a predisposition to other CNS tumours including meningiomas and astrocytomas [117]. Early diagnosis and treatment can prevent the neurological impairment but hearing is rarely preserved. At risk relatives can be monitored by regular audiometry and skin and eye examinations with MRI scans at intervals. The gene has been mapped to chromosome 22 and isolated in 1993 [118]. The protein product of the gene has been called merlin. Most of the mutations cause the synthesis of a truncated protein. An association between nonsense and frameshift mutations and clinical manifestations has been made. Mutations that cause premature truncation of the NF2 protein present with severe phenotypes [119]. In contrast, mutations that affect only a single amino acid have mild NF2. Subjects with truncating mutations have been shown to be significantly more likely to develop symptoms before 20 years of age and to develop at least 2 symptomatic CNS tumours in addition to vestibular schwannomas before 30 years of age [120]. Presymptomatic and prenatal diagnosis is therefore useful in the management of this condition.

\section{Gorlin Syndrome}

Gorlin syndrome or basal cell naevus syndrome is a relatively rare (approximately 1:57,000), autosomal dominant disorder associated with multiple basal cell carcinomas of the skin, and palmar and plantar pits [121]. In addition there are many other associated features including frontal and parietal bossing, prominent jaw, odontogenic keratocysts of the jaw, calcification of the falx and bifid, absent or rudimentary ribs. Surveillance is by annual dermatological investigations and regular monitoring of jaw cysts which can erode locally if left untreated. Radiation increases the incidence of the basal cell naevi so should not be used. Basal cell naevi and jaw cysts are present in $90 \%$ of gene carriers by age 40 [122]. The gene was mapped to chromosome 9q in 1992 [123] and was isolated in 1996 [124]. The gene is PTCH and mutation analysis has identified many mutations throughout 
the coding region, the majority of which are truncating [125]. No genotype-phenotype correlations have so far been found.

\section{Familial Gastric Cancer}

Gastric cancer is a major cause of death from cancer world-wide. Around 10\% of cases show familial clustering. In 1998, linkage in a large Maori pedigree was found to chromosome 16q21 [126]. The E cadherin gene (CDH1) lay within this region and SSCP analysis of the gene identified a band shift in exon 7 which when sequenced proved to be a splice site mutation. The consequence of this mutation was to alter splicing and introduce a premature stop codon. Analysis of two further families with early onset, histologically diffuse gastric cancer identified additional mutations in CDH1. E cadherin is a cell adhesion molecule which binds to $\beta$-catenin at adherence junctions preventing cell signalling. Loss of $E$ cadherin results in increased cell mobility. A second study of non-Maori families selected on the basis of either 2 cases of gastric cancer in first-degree relatives with one affected before age 50 years, or 3 or more cases of gastric cancer, identified mutations in 25\% of cases confirming a role for $\mathrm{E}$ cadherin in familial gastric cancer [127]. In addition, 1 of the mutation carriers in this study developed colorectal cancer at age 30, indicating that $\mathrm{CDH} 1$ may also be implicated in some cases of early onset colorectal cancer. However, only a proportion of familial gastric cancers can be accounted for by $\mathrm{CDH} 1$ mutations and other genes remain to be identified. Guidelines for the management of familial gastric cancers have recently been developed [128].

\section{Hereditary Prostate Cancer}

Prostate cancer is a major health problem accounting for over 8,000 deaths per year in the UK, and in the US is the second most common cause of death from cancer. A strong hereditary component to prostate cancer has been postulated. A gene for familial prostate cancer has been localised to chromosome 1q24-25 and named HPC1 [129]. However there is clear evidence of locus heterogeneity and other possible candidate genes have been identified [129].

\section{Conclusion}

This review has highlighted the benefits of mutation screening and presymptomatic diagnosis in families with a strong history of cancer. Further genes are likely to be identified in the immediate future, especially with the recent publication of the entire sequence of the human genome. This will mean increased benefits for patients with the ability to target screening to high-risk individuals. In addition, there will be cost benefits to health services. As well as benefiting those individuals with familial cancers, it will potentially offer insight into the molecular defects in sporadic cancer, and alternative chemotherapeutic options should also become available. The first 10 years of this millennium are therefore likely to bring many advances in the field of cancer research and molecular diagnostics. 


\section{References}

1 Macdonald F, Ford $\mathrm{CH}$ : Molecular Biology of Cancer. Oxford, Bios Scientific Publishers, 1997.

2 Peterson GM, Brensinger JD, Johnson KA, Giardello FM: Genetic testing and counseling for hereditary forms of colorectal cancer. Cancer 1999:86:2540-2550.

3 Terdiman JP, Conrad PG, Sleisenger $\mathrm{MH}$ : Genetic testing in hereditary colorectal cancer: Indications and procedures. Am J Gastroenterol 1999;94:2344-2356.

4 Sijmonds RH, Boonstra AE, Reefhuis $\mathrm{J}$, Hordijk-Hos JM, de Walle HE, Oosterwijk JC, Cornel MC: Accuracy of family history of cancer. Eur J Hum Genet 2000;8:181-186.

5 Clarke A (ed): The Genetic Testing of Children. Oxford, Bios Scientific Publishers, 1998.

6 Burn J, Chapman P, Delhanty J: The UK Northern region genetic register for familial adenomatous polyposis coli: Use of age of onset, congenital hypertrophy of the retinal pigment epithelium and DNA markers in risk calculations. J Med Genet 1991;28:289-296.

7 Eccles DM, Lunt PW, Wallis Y, Griffiths M, Sandhu B, McKay S, Morton D, Shea Simonds J, Macdonald F: An unusually severe phenotype for familial adenomatous polyposis. Arch Dis Child 1997;77:431-435.

8 Eccles DM, Evans DG, McKay J: Guidelines for a genetic risk based approach to advising women with a family history of breast cancer. $\mathrm{J}$ Med Genet 2000;37:203-209.

9 Lapham EV, Kozma C, Weiss JO: Genetic discrimination perspectives of consumers. Science 1996;274: 621-624.

10 Rodriguez-Bigas MA, Vasen HP, O'Mallery L: Health, life and disability insurance and hereditary non-polyposis colorectal cancer. Am J Hum Genet 1998;736-737.

11 Morton DG, Macdonald F, CachonGonzales MB, Rindl PM, Neoptolemos JP, Keighley MR, Delhanty JD, McKeown CM, Kilpatrick M, Hulten MA: The use of DNA from paraffin wax preserved tissue for predictive diagnosis in familial adenomatous polyposis. J Med Genet 1992; 29:571-573.
12 Langren U (ed): Laboratory Protocols in Mutation Detection. Oxford, Oxford University Press, 1996.

13 Cotton RGH, Edkins E, Forrest S (eds): Mutation Detection: A Practical Approach. Oxford, Oxford University Press, 1998.

14 van der Luijt R, Khan PM, Vasen $H$, van Leeuwen C, Tops C, Roest P, den Dunnen J, Fodde R: Rapid detection of translation-terminating mutations at the adenomatous polyposis coli (APC) gene by direct protein truncation test. Genomics 1994;20:1-4.

15 Dunlop MG, Farrington SM, Carothers $\mathrm{AD}$, Wyllie AH, Sharp L, Burn J, Kinzler K, Vogelstein B: Cancer risk associated with germline mismatch repair gene mutations. Hum Mol Genet 1997;6:105110.

16 Morton DG, Macdonald F, Haydon J, Cullen R, Barker G, Hulten M, Neoptolemos JP, Keighley MR McKeown C: Screening practice for familial adenomatous polyposis: The potential for regional registers. Br J Surg 1993;80:255-258.

17 Bussey HJ: Familial polyposis coli: Family studies, histopathology, differential diagnosis and results of treatment. Baltimore, Johns Hopkins Press, 1975.

18 Vasen HF, Griffoen G, Offerhaus GJ: The value of screening and central registration of families with familial adenomatous polyposis: A study of 82 families in the Netherlands. Dis Colon Rectum 1990;33: 227-230.

19 Bodmer WF, Bailey CJ, Bodmer J, Bussey HJ, Ellis A, Gorman P, Lucibello FC, Murday VA, Rider SH, Scambler P: Localization of the gene for familial adenomatous polyposis on chromosome 5. Nature 1987; 328:614-616.

20 Kinzler KW, Nilbert MC, Su LK, Vogelstein B, Bryan TM, Levy DB, Smith KJ, Preisinger AC, Hedge P, McKechnie D, Finniear R, Markham A, Groffen J, Boguski MS, Altschul SF, Horii A, Ando H, Miyoshi Y, Miki Y, Nishisho I, Nakamura Y: Identification of FAP locus genes from chromosome $5 \mathrm{q} 21$. Science 1991;253:661-665.
21 Joslyn G, Carlson M, Thliveris A, Albertsen H, Gelbert L, Samowitz W, Groden J, Stevens J, Spirio L, Robertson M, Sargeant L, Krapcho K, Wolff E, Burt R, Hughes JP, Warrington $\mathrm{J}$, McPherson $\mathrm{J}$, Wasmuth J, Le Paslier D, Abderrahim $\mathrm{H}$, Cohen D, Leppert M, White R: Identification of deletion mutations and three new genes at the familial polyposis locus. Cell 1991;66:601613.

22 Xia L, St Denis KA, Bapat B: Evidence for a novel exon in the coding region of the adenomatous polyposis coli (APC) gene. Genomics 1995;28: 589-591

23 Rubinfield R, Souza B, Albert I, Muller O, Chamberlain SH, Masiarz FR, Munemitsu S, Polakis P: Association of the APC gene product with beta-catenin. Science 1993; 262:1731-1734.

24 Peifer M: Regulating cell proliferation: As easy as APC. Science 1996; 272:974-975.

25 Wallis YL, Morton DG, McKeown CM, Macdonald F: Molecular analysis of the APC gene in 205 families: Extended genotype-phenotype correlations in FAP and evidence for the role of APC amino acid changes in colorectal cancer predisposition. $\mathbf{J}$ Med Genet 1999;36:14-20.

26 Van der Luijt RB, Khan PM, Vasen HF, Tops CM, van Leeuwen-Cornelisse IS, Wijnen JT, van der Klift HM, Plug RJ, Griffioen G, Fodde R: Molecular analysis of the APC gene in 105 Dutch kindreds with familial adenomatous polyposis: 67 germline mutations identified by DGGE, PTT, and Southern analysis. Hum Mutat 1997;9:7-16.

27 Laken SJ, Petersen GM, Gruber SB, Oddoux C, Ostrer H, Giardiello FM, Hamilton SR, Hampel H, Markowitz A, Klimstra D, Jhanwar S, Winawer S, Offit $\mathrm{K}$, Luce $\mathrm{MC}$, Kinzler KW, Vogelstein B: Familial colorectal cancer in Ashkenazim due to a hypermutable tract in APC. Nat Genet 1997;17:79-83. 
28 Frayling IM, Beck NE, Ilyas M, Dove-Edwin I, Goodman P, Pack K, Bell JA, Williams CB, Hodgson SV, Thomas HJ, Talbot IC, Bodmer WF, Tomlinson IP: The APC variants I1307K and E1317Q are associated with colorectal tumors, but not always with a family history. Proc Natl Acad Sci USA 1998;95:1072210727.

29 Varesco L, Gismondi V, James R, Robertson M, Grammatico P, Groden J, Casarino L, De Benedetti L, Bafico A, Bertario L, Sala P, Sassatelli R, Ponz de Leon M, Biasco G, Allegretti A, Aste H, De Sanctis S, Rossetti C, Illeni MT, Sciarri A, Del Porto G, White R, Ferrara GB: Identification of APC gene mutations in Italian adenomatous polyposis coli by PCR-SSCP analysis patients. Am J Hum Genet 1993;52: 280-285.

30 Wallis YL, Macdonald F, Hulten M, Morton JE, McKeown CM, Neoptolemos JP, Keighley M, Morton DG: Genotype-phenotype correlation between position of constitutional APC gene mutation and CHRPE expression in familial adenomatous polyposis. Hum Genet 1994;94: 543-548.

31 Dobbie Z, Spycher M, Mary JL, Haner M, Guldenschuh I, Hurliman $\mathrm{R}$, Amman R, Roth J, Muller H, Scott RJ: Correlation between the development of extra colonic manifestations in FAP patients and mutations beyond codon 1403 in the APC gene. J Med Genet 1996;33: 274-280.

32 Olschwang S, Tiret A, Laurent-Puig P, Muleris M, Parc R, Thomas G: Restriction of ocular fundus lesions to a specific subgroup of APC mutations in adenomatous polyposis coli patients. Cell 1993;75:959-968.

33 Caspari R, Olschwang S, Friedl W, Mandl M, Boisson C, Boker T, Augustin A, Kadmon M, Moslein G, Thomas G, Propping P: Familial adenomatous polyposis: Desmoid tumours and lack of ophthalmic lesions (CHRPE) associated with APC mutations beyond codon 1444. Hum Mol Genet 1995;4:337-340.
34 Eccles DM, van der Luijt R, Breukel C, Bullman H, Bunyan D, Fisher A, Barber J, du Boulay C, Primrose J, Burn J, Fodde R: Hereditary desmoid disease due to a frame shift mutation at codon 1924 of the APC gene. Am J Hum Genet 1996;59: 1193-1201.

35 Nagase H, Miyoshi Y, Horii A, Aoki $\mathrm{T}$, Ogawa M, Utsunomiya J, Baba S, Sasazuki T, Nakamura Y: Correlation between the location of germline mutations in the APC gene and the number of colorectal polyps in familial adenomatous polyposis patients. Cancer Res 1992;52:40554057.

36 Caspari R, Friedl W, Mandl M, Moslein G, Kadmon M, Knapp M, Jacobasch KH, Ecker KW, Kreissler-Haag D, Timmermanns G, Propping P: Familial adenomatous polyposis: Mutation at codon 1309 and early onset of colon cancer. Lancet 1994;343:629-632.

37 Spirio L, Olschwang S, Groden J, Robertson M, Samowitz W, Joslyn G, Gelbert L, Thliveris A, Carlson M, Otterud B, Lynch H, Watson P, Lynch P, Laurent-Puig P, Burt R, Hughes JP, Thomas G, Leppert M, White R: Alleles of the APC gene: An attenuated form of familial polyposis. Cell 1993;75:951-957.

38 Moser AR, Mattes EM, Dove WF, Lindstrom MJ, Haag JD, Gould $\mathrm{MN}$ : ApcMin, a mutation in the murine Apc gene, predisposes to mammary carcinomas and focal alveolar hyperplasias. Proc Natl Acad Sci USA 1993;90:8977-8981.

39 MacPhee M, Chepenik KP, Liddell RA, Nelson KK, Siracusa LD, Buchberg AM: The secretory phospholipase A2 gene is a candidate for the MOM1 locus, a major modifier of $\mathrm{APC}^{\mathrm{min}}$ induced intestinal neoplasia. Cell 1995;81:957-966.

40 Lynch HT, De la Chapelle A: Genetic susceptibility to non-polyposis colorectal cancer. J Med Genet 1999;36:801-818.

41 Burke W, Peterson G, Lynch P, Botkin J, Daly M, Kahn MJ, McTiernan A, Offit K, Thomson E, Varricchio C, Garber J: Recommendations for follow-up care of individuals with an inherited predisposition to cancer. 1. Hereditary non-polyposis colon cancer. JAMA 1997;277: 915-919.
42 Vasen HF, Mecklin JP, Khan PM, Lynch HT: The international collaborative group on hereditary nonpolyposis colorectal cancer (ICGHNPCC). Dis Colon Rectum 1991; 34:424-425.

43 Rodriguez-Bigas MA, Boland CR, Hamilton SR, Henson DE, Jass JR, Khan PM, Lynch H, Perucho M, Smyrk T, Sobin L, Srivastava S: A Natinal Cancer Institute Workshop on Hereditary Nonpolyposis Colorectal Cancer Syndrome: Meeting highlights and Bethesda guidelines. J Natal Cancer Inst 1997;89:17581762.

44 Peltomaki P, Aaltonen L, Sistonen P, Pylkkanen L, Mecklin JP, Jarvinen $\mathrm{H}$, Green JS, Weber JL, Leach FS, Paterson GM, Hamilton SR, de la Chapelle A, Vogelstein B, Jass JR: Genetic mapping of a locus predisposing to colorectal cancer. Science 1993;260:810-812.

45 Lindblom A, Tannergard P, Werelius B, Nordenskjold M: Genetic mapping of a second locus predisposing to hereditary non-polyposis colon cancer. Nat Genet 1993;5: 279-282.

46 Aaltonen L, Peltomaki P, Leach FS, Sistonen P, Pylkkanen L, Mecklin JP, Jarvinen H, Powell SM, Jen J, Hamilton SR, Petersen GM, Kinzler KW, Vogelstein B, de la Chapelle A: Clues to the pathogenesis of familial colorectal cancer. Science 1993;260: 812-816.

47 Ionov Y, Peinado MA, Mlakhosyan S, Shibata D, Peruchio M: Ubiquitous somatic mutations in simple repeated sequences reveal a new mechanism for colonic carcinogenesis. Nature 1993;363:558-561.

48 Strand M, Prolla TA, Liskay RM, Petes TD: Destabilisation of tracts of simple repetitive DNA in yeast by mutations affecting DNA mismatch repair. Nature 1993;365:274-276.

49 Fishel R, Lescoe MK, Rao MR, Copeland NG, Ienkins NA, Garber J, Kane M, Kolodner R: The human mutator gene homolog MSH2 and its association with hereditary nonpolyposis colon cancer. Cell 1994; 77:167. 
50 Bronner Ce, Baker SM, Morrison PT, Warren G, Smith LG, Lescoe MK, Kane M, Earabino C, Lipford J, Lindblom A, Tannergard P, Bollag RJ, Godwin AR, Ward DC, Nordensjold M, Fishel R, Kolodner R, Liskay RM: Mutation in the DNA mismatch repair gene homologue hMLH1 is associated with hereditary non-polyposis colon cancer. Nature 1994:368:258-261.

51 Nicolaides NC, Papadopoulos N, Liu B, Wei YF, Carter CK, Ruben SM, Rosen CA, Haseltine WA, Fleischmann RD, Fraser CM, Adams MD, Venter JC, Dunlop MG, Hamilton SR, Patersen G, de la Chapelle A, Vogelstein B, Kinzler K: Mutations of two PMS homologues in hereditary nonpolyposis colon cancer. Nature 1994;371:75-80.

52 Miyaki M, Konishi M, Tanaka K, Kikuchi-Yanoshita R, Muraoka M, Yasuno M, Igari T, Koike M, Chiba M, Mori T: Germline mutation of MSH6 as the cause of hereditary non-polyposis colorectal cancer. Nat Genet 1997;17:271-272.

53 Wijnen I, Khan PM, Vasen H, Menko F, van der Klift $\mathrm{H}$, van den Broek $M$, van Leeuwen-Cornelisse I, Nagengast $F$, Meijers-Heijboer EJ, Lindhout D, Griffiosen G, Cats A, Kleibeuker J, Varesco L, Bertario L, Bisgaard M, Mohr J, Jolodner R, Fodde R: Majority of hMLH1 mutations responsible for hereditary nonpolyposis colon cancer cluster at the exonic region 15-16. Am J Hum Genet 1996;58:300-307.

54 Peltomaki P: DNA mismatch repair gene mutations in human cancer. Environ Health Perspect 1997;105: 775-780.

55 Nystrom-Lahti M, Kristo P, Nicolaides NC, Chang SY, Aaltonen LA, Moisio AL, Jarvinen H, Mecklin JP, Kinzler KW, Vogelstein B, de la Chappelle A, Peltmaki P: Founding mutations and Alu mediated recombination in hereditary colon cancer. Nat Med 1995;1:1203-1206.

56 Nystrom-Lahti M, Wu Y, Moisio AL, Hofstra RM, Osinga J, Mecklin JP, Jarvinen HJ, Leisti J, Buys CH, de la Chapelle A, Peltomaki P: DNA mismatch repair gene defects in 55 kindreds with verified or putative hereditary nonpolyposis colorectal cancer. Hum Mol Genet 1996;5: 763-769.

The Impact of Presymptomatic

Molecular Testing in Hereditary

Cancers
57 Froggatt NJ, Green J, Brassett C, Evans DG, Bishop DT, Kolodner R, Maher ER: A common MSH2 mutation in English and North American HNPCC families: Origin, phenotypic expression and sex specific differences in colorectal cancer. $\mathrm{J}$ Med Genet 1999;36:97-102.

58 Shimodaira H, Filosi N, Shibata H, Suzuki T, Radice P, Kanamaru R, Friend S, Kolodner RD, Ishioka C: Functional analysis of human MLH1 mutations in Saccharomyces cerevisae. Nat Genet 1998;19:384389.

59 Aaltonen L, Salovaara R, Kristo P Canzain F, Hemminki A, Peltomatki P, Chadwick RB, Kaariainen H, Eskelinen M, Jarvinen H, Mecklin JP, de la Chapelle A: Incidence of hereditary nonpolyposis colorectal cancer and the feasibility of molecular screening for the disease. $\mathrm{N} \mathrm{Engl}$ J Med 1998;338:1481-1487.

60 Wijnen J, Vasen HF, Khan PM, Zwinderman $\mathrm{AH}$, van der Klift $\mathrm{H}$ Mulder A, Tops C, Moller P, Fodde $\mathrm{R}$ : Clinical findings with implications for genetic testing in families with clustering of colorectal cancer. N Engl J Med 1998;339:511-518.

61 Loukola A, de la Chapelle A, Aaltonen L: Strategies for screening for hereditary nonpolyposis colorectal cancer. J Med Genet 1999;36:819822.

62 Bapat B, Madlensky L, Temple LK, Hiruki T, Redston M, Baron DL, Xia L, Marcus VA, Soravia C, Mitri A, Shen W, Gryfe R, Berk T, Chodirker BN, Cohen Z, Gallinger S: Family history characteristics, tumour microsatellite instability and germline MSH2 and MLH1 mutations in hereditary colorectal cancer. Hum Genet 1999;104:167-176.

63 Vasen HF, Wijnen JT, Menko FH, Kleibeuker JH, Taal BG, Griffioen G, Nagengast FM, Meijers-Heijboer EH, Bertario L, Varesco L, Bisgaard ML, Mohr J, Fodde R, Khan PM: Cancer risk in families with hereditary nonpolyposis colorectal cancer diagnosed by mutation analysis. Gastroenterology 1996;110:10201027.
64 Giardiello FM, Brensinger JD, Petersen GM, Luce MC, Hylind LM, Bacon JA, Booker SV, Parker RD, Hamilton SR: The use and interpretation of commercial APC gene testing for familial adenomatous polyposis. N Engl J Med 1997;336:823827.

65 Hawk E, Lubert R, Limburg P: Chemoprevention in hereditary colon cancer. Cancer 1999;86:2551-2563.

66 Ruschoff J, Walinger S, Dietmaier W: Aspirin suppresses the mutator phenotype associated with hereditary nonpolyposis colorectal cancer by genetic selection. Proc Natl Acad Sci USA 1998;95:11301-11306.

67 Cromwell DM, Moore RD, Bresinger JD, Petersen GM, Bass EB, Giardiello FM: Cost analysis of alternative approaches to colorectal screening in familial adenomatous polyposis. Gastroenterology 1998; 114:893-901.

68 Hall JM, Friedman L, Guenther C, Lee MK, Weber JL, Black DM, King M-C: Closing in on a breast cancer gene on chromosome 17q. Am J Hum Genet 1992;50:12351242.

69 Easton DF, Bishop DT, Ford D Crockford GP: Breast Cancer Linkage Consortium: Genetic linkage analysis in familial breast and ovarian cancer: Results from 214 families. Am J Hum Genet 1993;52: 678-701.

70 Miki Y, Swensen J, Shattuck-Eidens D, Futreal PA, Harshamn K, Tavtigian S, Liu Q, Cochran C, Bennett LM, Ding W, Bell R, Rosenthal J, et al: A strong candidate for the breast and ovarian cancer susceptibility gene BRCA1. Science 1994;266:6671.

71 Wooster R, Bignell G, Lancaster J, Swift S, Seal S, Mangion J, Collins N, Gregory S, Gumbs C, Micklem G, Barfoot R, Hamoudi R, Patel S, Rice C, Biggs P, Hashim Y, Smith A, Connor F, Arason A, Gudmundsson J, Ficenec D, Keisell D, Ford D, Tonin P, Bishop DT, Spurr NK, Ponder BA, Eeles R, Peto J, Devilee P, Comelisse C, Lynch H, Narod S, Lenoir G, Egilsson V, Barkadottir RB, Easton DF, Bentley DR, Futreal PA, Ashworth A, Stratton MR: Identification of the breast cancer susceptibility gene BRCA2. Nature 1995;378:789-792. 
72 Wooster R, Neuhausen SL, Mangion J, Quirk Y, Ford D, Collin N, Nguyen K, Seal S, Tran T, Averill D, Fields P, Marshall G, Narod S, Lenoir GM, Lynch H, Feunteun J, Devilee $\mathrm{P}$, Comelisse CJ, Menko FH, Daly PA, Ormiston W, McManus R, Pye C, Lewis CM, Cannon-Albright LA, Peto J, Ponder BA, Skolnick $\mathrm{MH}$, Easton DF, Goldgar DE, Stratton MR: Localization of a breast cancer susceptibility gene, BRCA2, to chromosome 13q12-13. Science 1994;265:2088-2090.

73 Gayther SA, Harrington P, Russell P, Kharkevich G, Garkavtseva RF, Ponder BA, UKCCCR Familial Ovarian Cancer Study Group: Rapid detection of regionally clustered germ-line BRCA1 mutations by multiplex heteroduplex analysis. Am J Hum Genet 1996;58:451456.

74 Hogervorst FB, Comelis RS, Bout $\mathrm{M}$, van Vliet M, Oosterwijk JC, Olmer R, Bakker B, Klijn JG, Vase $\mathrm{HF}$, Meijers-Heijboer $\mathrm{H}$, Menko FH, Comelisse CJ, den Dunnen JT, Devilee P, van Ommen GJ: Rapid detection of BRCA1 mutations by the protein truncation test. Nat Genet 1995;10:208-212.

75 Struewing JP, Abeliovich D, Peretz T, Avishai N, Kaback MM, Collins FS, Brody LC: The carrier frequency of the BRCA1 185delAG mutation is approximately 1 percent in Ashkenazi Jewish individuals. Nat Genet 1995;11:198-200.

76 Neuhausen S, Gilewski T, Norton L, Tran T, McGuire P, Swensen J, Hampel H, Borgen P, Brown K, Skolnick M, Shattuck-Eidens D, Jhanwar S, Goldgar D, Offit K: Recurrent BRCA2 6174delT mutations in Ashkenazi Jewish women affected by breast cancer. Nat Genet 1996;13:126-128.

77 Abeliovich D, Kaduri L, Lerer I, Weinberg N, Amir G, Sagi M, Zlotogora J, Heching N, Peretz T: The founder mutation 185delAG and 5382insC in BRCA1 and 6174delT in BRCA2 appear in $60 \%$ of ovarian cancer and $30 \%$ of early onset breast cancer patients among Ashkenazi women. Am J Hum Genet 1997;60: 505-514.
78 Thorlacius S, Tryggvadottir L, Olafsdottir GH, Jonasson JG, Ogmundsdottir HM, Tulinius H, Eyfjord JE: Linkage to BRCA2 region in hereditary male breast cancer. Lancet 1995;346:544-545.

79 Petrij-Bosch A, Peelen T, van Vliet M, van Eijk R, Olmer R, Drusedau M, Hogervorst FB, Hageman S, Arts PJ, Ligtenberg MJ, Meijers-Heijboer H, Klijn JG, Vasen HF, Cornelisse CJ, van Veer LJ, Bakker E, van Ommen GJ, Devilee P: BRCA1 genomic deletions are major founder mutations in Dutch breast cancer patients. Nat Genet 1997;17:341345.

80 Tonin PN, Mes-Masson AM, Futreal PA, Morgan K, Mahon M, Foulkes WD, Cole DE, Provencher D, Ghadirian P, Narod SA: Founder BRCA1 and BRCA2 mutations in French Canadian breast and ovarian cancer families. Am J Hum Genet 1998;63:1341-1351.

81 Gayther SA, Warren W, Mazoyer S, Russell PA, Harrington PA, Chiano M, Seal S, Hamoudi R, van Rensburg EJ, Dunning AM, Love R, Evans G, Easton D, Clayton D, Stratton MR, Ponder BA: Germline mutations of the BRCA1 gene in breast and ovarian cancer families provide evidence for a genotypephenotype correlation. Nat Genet 1995;11:428-433.

82 Gayther SA, Mangion J, Russell P, Seal S, Barfoot R, Ponder BA, Stratton MR, Easton D: Variation of risks of breast and ovarian cancer associated with different germline mutations of the BRCA2 gene. Nat Genet 1997;15:103-105.

83 Ford D, Easton DF, Stratton M, Narod S, Goldgar D, Devilee P, Bishop DT, Weber B, Lenoir G, ChangClaude J, Sobol H, Teare MD, Struewing J, Arason A, Scherneck S, Peto J, Rebbeck TR, Tonin P, Neuhausen S, Barkardottir R, Eyfjord J, Lynch H, Ponder BA, Gayther SA, Zelada-Hedman M, et al: Genetic heterogeneity and penetrance analysis of the BRCA1 and BRCA2 genes in breast families. Am J Hum Genet 1998;62:676-689.
84 Easton DF, Steele L, Fields P, Ormiston W, Averill D, Daly PA, McManus R, Neuhausen SL, Ford D, Wooster R, Cannon-Albright La, Stratton MR, Goldgar DE: Cancer risks in two large breast cancer families linked to BRCA2 on chromosome 13q12-13. Am J Hum Genet 1997;61:120-128.

85 Easton DF, Ford D, Bishop DT: Breast Cancer Linkage Consortium: Breast and ovarian cancer incidence in BRCA1-mutation carriers. Am J Hum Genet 1995;56:265-271.

86 Bassett JH, Forbes SA, Pannett AA, Lloyd SE, Christie PT, Wooding C, Harding B, Besser GM, Edwards CR, Monson JP, Sampson J, Wass JA, Wheeler MH, Thakker RV: Characterisation of mutations in patients with multiple endocrine neoplasia type 1. Am J Hum Genet 1998;62:232-244.

87 Larsson C, Skogseid B, Oberg K, Nakamura Y, Nordenskold M: Multiple endocrine neoplasia type 1 gene maps to chromosome 11 and is lost in insulinomas. Nature 1988; 332:85-87.

88 European Consortium on MEN1: Identification of the multiple endocrine neoplasia type 1 (MEN1) gene. Hum Mol Genet 1997;6:11771183.

89 European Consortium on MEN1. The search for the MEN1 gene. J Int Med 1998;243:441-446.

90 Marx SJ, Agarwal SK, Kester MB, Heppner C, Kim YS, Emmert-Buck MR, Debelenko LV, Lubensky IA, Zhuang Z, Guru SC, Manickam P, Olufemi SE, Skarulis MC, Doppman JL, Alexander RH, Liotta LA, Collins FS, Chandrasekharappa SC, Spiegel AM, Burns AL: Germline and somatic mutation of the gene for multiple endocrine neoplasia type1 (MEN1). J Int Med 1998;243: 447-453.

91 Trump D, Farren B, Wooding C, Pang JT, Besser GM, Buchanan KD, Edwards CR, Heath DA, Jackson $\mathrm{CE}$, Jansen S, Lips K, Monson JP, O'Hallonan D, Sampson J, Shalet SM, Wheeler MH, Zink A, Thakker RV: Clinical studies of multiple endocrine neoplasia type 1 (MEN1): Q J Med 1996;89:653-669. 
92 Thakker RV: The molecular genetics of the multiple endocrine neoplasia syndromes. Clin Endocrinol (Oxf) 1993;38:1-14.

93 Mathew CG, Chin KS, Easton DF, Thorpe K, Carter C, Liou GI, Fong SL, Bridges CD, Haak H, Kruseman AC, Schifter S, Hansen HH, Telenius H, Telenius-Berg M, Ponder BJ: A linked genetic marker for multiple endocrine neoplasia type $2 \mathrm{~A}$ on chromosome 10. Nature 1987;328:527-528.

94 Donis-Keller H, Dou S, Chi D, Carlson KM, Toshima K, Lairmore TC, Howe JR, Moley JF, Goodfellow P, Wells SA Jr: Mutations in the RET proto-oncogene are associated with MEN2A and FMTC. Hum Mol Genet 1993;2: 851-856.

95 Mulligan LM, Kwok JB, Healey CS, Elsdon MJ, Eng C, Gardner E, Love DR, Mole SE, Moore JK, Papi L, Ponder MA, Telenius H, Tunnacliffe A, Ponder BA: Germline mutations of the RET protooncogene in multiple endocrine neoplasia type 2A. Nature 1993; 363:458-460.

96 Mulligan LM, Eng C, Attie T, Lyonnet S, Marsh DJ, Hyland VJ, Robinson BG, Frilling A, VerellenDumoulin C, Safar A: Diverse phenotypes associated with exon 10 mutations of the RET protooncogene. Hum Mol Genet 1994; 3:2163-2167.

97 Mak YF, Ponder BA: RET oncogene. Curr Opin Genet Dev 1996; 6:82-86.

98 Edery P, Lyonnet S, Mulligan LM, Pelet A, Dow E, Abel L, Holder S, Nihoul-Fekete C, Ponder BA, Munnich A: Mutations of the RET proto-oncogene in Hirschsprung's disease. Nature 1994;367:378380.

99 Maher ER, Iselius L, Yates JR, Littler M, Benjamin C, Harris R, Sampson J, Williams A, FergusonSmith MA, Morton N: Von Hippel-Lindau disease: A genetic study. J Med Genet 1991;28:443447.

100 Moore AT, Maher ER, Rosen P, Gregor Z, Bird AC: Ophthalmological screening for von HippelLindau disease. Eye 1991;5:723728 .

The Impact of Presymptomatic Molecular Testing in Hereditary Cancers
101 Seizinger BR, Rouleau GA, Ozelius LJ, Lane AH, Farmer GE, Lamiell JM, Haines J, Yuen W, Collins D, Majoor-Krakauer DJ: Von Hippel-Lindau disease maps to the region of chromosome 3 associated with renal cell carcinoma. Nature 1988;332:268-269.

102 Maher ER, Bentley E, Yates JR Latif F, Lerman M, Zbar B, Affara NA, Ferguson-Smith MA: Mapping of the von Hippel-Lindau disease locus to a small region of chromosome $3 p$ by genetic linkage analysis. Genomics 1991;10:957960.

103 Latif F, Tory K, Gnarra J, Yao M, Duh FM, Orcutt ML, Stackhouse T, Kuzmin I, Modi W, Geil L, Schmidt L, Zhou F, Li H, Wei $\mathrm{MH}$, Chen F, Glenn G, Choyke P, Walther MM, Weng Y, Duan DS, Dean M, Glavac D, Richards FM, Crossey PA, Ferguson-Smith MA, Le Paslier D, Chumakov I, Cohen D, Chinault AC, Maher ER, Linehan WM, Zbar B, Lerman MI: Identification of the von HippelLindau disease tumor suppressor gene. Science 1993;260:13171320.

104 Kaelin WG Jr, Maher ER: The VHL tumour 14-suppressor gene paradigm. Trends Genet 1998;14: 423-426.

105 Crossey PA, Richards FM, Foster $\mathrm{K}$, Green JS, Prowse A, LAtif F, Lerman MI, Zbar B, Affara NA, Ferguson-Smith MA, Maher ER: Identification of intragenic mutations in the von Hippel-Lindau disease tumour suppressor gene and correlation with disease phenotype. Hum Mol Genet 1994;3: 1303-1308.

106 Chen F, Kishida T, Yao M, Hustad T, Glavac D, Dean M, Gnarra JR, Orcutt ML, Duh FM, Glenn G, Green J, Hsia YE, Lamiell J, Li H, Wei MH, Schmidt L, Tory K, Kuzman I, Stackhouse T, Latif F, Lineham WM, Lerman M, Zbar B: Germline mutations in the von Hippel-Lindau disease tumor suppressor gene: Correlations with phenotype. Hum Mutat 1995;5: 66-75.
107 Zbar B, Kishida T, Chen F, Schmidt L, Maher ER, Richards FM, Crossey PA, Webster AR, Affara NA, Ferguson-Smith MA, Brauch H, Glavac D, Neumann HP, Tisherman S, Mulvihill JJ, Gross DJ, Shuin T, Whaley J, Seizinger B, Kley $\mathrm{N}$, Olschwang $\mathrm{S}$, Boisson C, Richard S, Lips $\mathrm{CH}$, Lerman M, et al: Germline mutations in the Von Hippel-Lindau disease (VHL) gene in families from North America, Europe, and Japan. Hum Mutat 1996;8:348357.

108 Stolle C, Glenn G, Zbar B, Humphrex JS, Choyke P, Walther M, Pack S, Hurley K, Audrey C, Klausner R, Linehan WM: Improved detection of germline mutations in the von Hippel-Lindau disease tumor suppressor gene. Hum Mutat 1998;12:417-423.

109 Li FP, Fraumeni JF: Prospective study of a cancer family syndrome. JAMA 1982;247:2692-2694.

110 Li FP, Fraumeni JF, Mulvihill JJ, Blattner WA, Dreyfus MG, Tucker MA, Miller RW: A cancer family syndrome in twenty-four kindreds. Cancer Res 1988;48:5358-5362.

111 Birch JM, Hatley AL, Tricker KJ, Prosser J, Condie A, Kelsey AM, Harris M, Jones PH, Binchey A, Crowther D, Craft AW, Eden OB, Evans DG, Thompson E, Mann JR, Martin J, Mitchell EL, Santibanez-Koref MF: Prevalence and diversity of constitutional mutations in the p53 gene among $21 \mathrm{Li}$ Fraumeni families. Cancer Res 1994;54:1298-1304.

112 Malkin D, Li FP, Strong LC, Fraumeni JF, Nelson CE, Kim DH, Kassel J, Gryka MA, Bischoff FZ, Tainsly MA, Friend SH: Germline p53 mutations in a familial syndrome of breast cancer, sarcomas and other neoplasms. Science 1990;250:1233-1238.

113 Varley JM, Evans DG, Birch JM: Li-Fraumeni syndrome: A molecular and clinical review. Br J Cancer 1997;76:1-14.

114 Huson SM, Hughes RA (eds): The Neurofibromatoses: A Pathologenetic and Clinical Overview. London, Chapman \& Hall, 1994. 
115 Wallace MR, Marchuk DA, Anderson LB: Type 1 neurofibromatosis gene: Identification of a large transcript disrupted in three NFI patients. Science 1990;249:181186.

116 Shen MH, Harper PS, Upadhyaya M: Molecular genetics of neurofibromatosis. J Med Genet 1996;33: 2-17.

117 Evans DG, Huson SM, Donnai D, Neary W, Blair V, Newton V, Harris R: A clinical study of type 2 neurofibromatosis. Q J Med 1992; 84:603-618.

118 Trofatter JA, MacCollin MM, Rutter JL, Murrell JR, Duyao MP, Parry DM, Eldridge R, Kley N, Menon AG, Pulaski K, Haase VH, Ambrose CM, Munroe D, Bove C, Haines JL, Martuza RL, MacDonald ME, Seizinger BR, Short MP, Buckler AJ, Gusella JF: A novel moesin-, ezrin-, radixin-like gene is a candidate for the neurofibromatosis 2 tumor suppressor. Cell 1993;75:826.

119 Ruttledge MH, Andermann AA, Phelan CM, Claudio JO, Han FY, Chretien N, Rangaratnam S, MacCollin M, Short P, Parry D, Michels V, Riccardi VM, Weksberg R, Kitamura K, Bradburn JM, Hall BD, Propping P, Rouleau GA: Type of mutation in the neurofibromatosis type 2 gene (NF2) frequently determines severity of disease. Am J Hum Genet 1996; 59:331-342.
120 Evans DG, Trueman L, Wallace A, Collins S, Strachan T: Genotype/ phenotype correlations in type 2 neurofibromatosis (NF2): Evidence for more severe disease associated with truncating mutations. J Med Genet 1998;35:450-455.

121 Gorlin RJ: Nevoid basal-cell carcinoma syndrome. Medicine (Baltimore) 1987;66:98-113.

122 Evans DG, Ladusans EJ, Rimmer S, Burnell LD, Thakker N, Farndon PA: Complications of the naevoid basal cell carcinoma syndrome: Results of a population based study. J Med Genet 1993; 30:460-464

123 Farndon PA, Del Mastro RG, Evans DG, Kilpatric MW: Location of gene for Gorlin syndrome. Lancet 1992;339:581-582.

124 Johnson RL, Rothman AL, Xie J, Goodrich LV, Bare JW, Bonifas JM, Quinn AG, Myers RM, Cox DR, Epstein EH Jr, Scott MP: Human homolog of patched, a candidate gene for the basal cell nevus syndrome. Science 1996;272: 1668-1671.

125 Wicking C, Shanley S, Smyth I, Gillies S, Negus K, Graham S, Suthers G, Haites N, Edwards M, Wainwright B, Chenevix-Trench G: Most germ-line mutations in the nevoid basal cell carcinoma syndrome lead to a premature termination of the PATCHED protein, and no genotype-phenotype correlations are evident. Am J Hum Genet 1997;60:21-26.
126 Guilford P, Hopkins J, Harraway $\mathrm{J}$, Mcleod N, Harawira P, Taite $\mathrm{H}$, Scoular R, Miller A, Reeve AB: Ecadherin germline mutations in familial gastric cancer. Nature 1998; 392:402-405.

127 Richards FM, McKee SA, Rajpar MH, Cole TR, Evans DG, Jankowski JA, McKeown C, Sanders DS, Maher ER: Germline E-cadherin gene $(\mathrm{CDH} 1)$ mutations predispose to familial gastric cancer and colorectal cancer. Hum Mol Genet 1999;8:607-610.

128 Caldas C, Carneiro F, Lynch HT, Yokota J, Wiesner GL, Powell SM, Lewis FR, Huntsman DG, Pharoah PD, Jankowski JA, Macleod P, Vogelsang H, Keller G; Park KG, Richards FM, Maher ER, Gayther SA, Oliveira C, Grehan N, Wight D, Seruca R, Roviello F, Ponder BA, Jackson CE: Familial gastric cancer: Overview and guidelines for management. J Med Genet 1999;36:873-880.

129 Eales R, the UK Familial Prostate Study Co-Ordinating Group and the CRC/BPG UK Familial Prostate Cancer Study Collaborators: Genetic predisposition to prostate cancer. Prostate Cancer Prostate Dis 1999;2:9-15. 